\title{
The syntax of cemetery space
}

This chapter describes the physical organisation of early Anglo-Saxon cemetery space by detailing the repertoire of shared semiotics used to organise a cemetery, specifically: cemetery topography, clusters of graves or burial plots, grave density, grave orientation, burial rituals and material culture. It also considers cemeteries which combine multiple organisational strategies.

\section{Introduction: structuring mortuary semiotics}

Cemeteries are not simply places where people bury the dead; they are the product of social agents working within the confines of cultural practice and shared semiotic knowledge. Within cemetery space, people shared a conceptual understanding by participating in episodic narratives which were specific to that place and those people. Because of this, burial practice was not universal; it might be interpreted differently by local, regional and individual agents depending on their own circumstances and experiences. It is for these reasons that broad questions like ethnicity, religious practice or afterlife belief and cultural death ways have proved difficult to address (Lucy, 2000b). Sam Lucy (1998) touched on this issue when she considered the differences between cemeteries in East Yorkshire as the product of regional, rather than national, variations. This is a useful starting point: early Anglo-Saxon cemeteries do show regional variations, but they also show considerable localised variation where every site and every grave is different from others in a whole host of ways. Early Anglo-Saxon cemeteries were employed at a plurality of social scales simultaneously, from the individual to the local and regional, creating dissimilar sites which nonetheless shared broad conceptual ideas.

Early Anglo-Saxon burial grounds are recognisable because of the similarities to other sites - small barrows or mounds of earth cover some of the graves, and cemeteries are found in close proximity to a settlement 
and water (Arnold, 1997: 54-63). However, one cemetery is not all cemeteries, and the details will be unique to a particular community. For instance, only a few people in the Thames Valley, Kent or East Anglia would have been in a position to see another region's cemeteries, let alone participate in another group's funerals. Equally, a few people from one community might have travelled to another adjacent community to attend a single funeral event, but the primary influence on any specific site would have been from its contiguous populations. This means that cemeteries were not necessarily the product of societal-level decisions, but were organised locally using a repertoire of burial technologies which may, or may not, have shared similarities with any other site according to family, community and regional traditions operating within wider early medieval cultural boundaries.

The influences of individual agents operating locally would have had varying effects on cemetery aesthetic. Each burial and each cemetery had been 'designed' by different people, which would result in chronological and spatial variation. Each site and each grave would be different. From this perspective, it should not be a surprise to learn that all archaeologically excavated early Anglo-Saxon cemeteries look different, but the conceptual semiotics behind the organisation of many of these sites may have been very similar.

A useful perspective for considering mortuary rituals is to view funerals as staged events with active participants (Price, 2010). Each episode would have been different. Different people would have attended each funeral, depending on who was alive to be present at any one chronological point, and different people would have contributed to each funeral to degrees that were dictated by membership of a particular social group (Sayer, 2010). So, while we might see each cemetery as a single site and plausibly the product of a single community, it was also the result of various events at different times that included dissimilar participants who had their own unique experiences and perspectives. Each site had its own internal chronology and this dictated its shape and future development, as well as the nature of the burials. Therefore cemeteries were not just the focus of single-staged funeral events; they were an aesthetic, visually powerful tool that people used to recall the history of a community, their family and their genealogy. They were important for the development of individual and community memory (Williams, 2006; Devlin, 2007b). This was developed within the burial space where the living told stories about the dead and used the semiotic knowledge they shared literally to map the past onto a physical space. This story could change as further burials were added and as new generations reworked the contributions of their forerunners. 
Early Anglo-Saxon cemeteries were frequently small and only a few contained more than a couple of hundred graves. Mucking in Essex, West Heslerton in East Yorkshire, Morning Thorpe and Spong Hill (both in Norfolk) were all particularly large sites, with either 200 to 400 inhumations or many thousands of cremations. However, most cemeteries contained around one hundred graves and were in use for 75 to 150 years; although Wasperton (in Warwickshire) and Spong Hill had their origins in the fourth century AD and so were used for considerably longer (Carver et al., 2009; Hills and Lucy, 2013). Even at these large, long-lived sites burial did not take place every week, every month or even every year. Burials were infrequent but, because cemeteries are usually found adjacent to settlements, they would have hosted other gatherings too. In connecting the past and present, early Anglo-Saxon cemeteries became a narrative tool which contained semiotic messages in the form of mnemonic devices operating on an aesthetic level. This may have functioned at the scale of the grave where similarities in burial tradition and gravegoods are occasionally found in adjacent graves (Williams, 2006: 42). As we saw at Orpington (in Chapter 1), once a grave has been closed the memory of its contents is fragile and may be subject to change. Mnemonic devices would have been most effective at a cemetery scale visible for many years after the funeral. Some early Anglo-Saxon cemeteries were located next to ancient barrows, where old ditches were used to define one edge of the site and newly made small mounds were employed to highlight grave locations. Cemeteries also contained rows of graves, clusters of inhumations or (frequently) cremations and graves positioned on different orientations. These physical traits could be interpreted by members of the local community because they shared semiotic knowledge. Mortuary space was imbued with materially represented narratives, and while cemeteries may not have been mirrors of society they were constructed as representations of it, which went on to aid in the construction of contemporary community narratives (Williams and Sayer, 2009).

\section{Cemetery topography}

Early Anglo-Saxon cemeteries were often focused on earlier features such as monuments, buildings, ditches, roads and contemporary Anglo-Saxon barrows. Howard Williams (1997; 1998) investigated the reuse of prehistoric monuments as significant places for the location of burial grounds. He concluded that the use of visible ancient features enabled early Anglo-Saxon communities to ritually appropriate their environment, to propagate and generate myths about their origin and identity. The placement of seventh-century burials bordering the 
Roman villa at Eccles in Kent (Williams 1997), or sixth-century burials alongside the Romano-British temple on Gallows Hill, Swaffham Prior in Cambridgeshire (Malim, 2006), and beside the Romano-British bath house at Orpington, Kent (Palmer, 1984), tell us a great deal about what was visible in the Early Middle Ages and the importance that these ancient structures may have had (Figure 2.1). Equally the fifth- and sixth-century cemetery at Abingdon, Oxfordshire, was adjacent to a Bronze Age ring ditch (Leeds and Harden, 1936), and the small seventh-century sites at Marina Drive (Dunstable, Bedfordshire), Ports Down I (Hampshire) and Bargates (Dorset) were all situated close to Bronze Age barrows (Matthews, 1962; Jarvis, 1983; Corney et al., 1967). In fact, 61 per cent of those early Anglo-Saxon cemeteries that reused ancient features were located adjacent to round barrows (Williams, 1997: 17; 1998).

It is not enough simply to understand that the early Anglo-Saxons used ancient features to locate their cemeteries; it is also important to consider how they structured their sites around them. For example, Empingham II (Rutland), Morning Thorpe (Norfolk), Snape (Suffolk) and Shudy Camps (Cambridgeshire) all used earlier features to define one or more of their boundaries and shape at least one side of their site (Lucy, 2000b: 129-30; Devlin, 2007b: 57-8). Anglo-Saxon cemeteries did not just share adjacency with older monuments, they integrated them into their form and used them to provide structure. For example, an earlier ditch adjacent to the small seventh-century cemetery at Garton Slack II, East Yorkshire, influenced the location of burials, which were positioned on the same axis and in rows alongside it. The same is true for earlier cemeteries: Mucking II, Essex, was a large site consisting of more than 500 graves, the majority of which were situated between two parallel late Roman enclosure ditches (Hirst and Clark, 2009; Figure 2.2). In both of these examples the position of earlier, but still visible, topographic elements not only encouraged the placement of the cemetery, but also contributed to its shape and influenced how it developed. At Berinsfield, Oxfordshire, both the placement of burials and the orientation of the graves were determined by the location of a series of intersecting Roman ditches. The northernmost graves were positioned on a N/S axis along a Roman ditch oriented on the same axis; the southern graves were positioned parallel to an E/W aligned ditch, lost through later quarrying (Figure 2.2).

The graves on an E/W axis at Petersfinger, Wiltshire, appear to surround a now absent barrow and at Deal, Kent, the presence of a single large Bronze-Age ring ditch, presumably a round barrow, not only influenced the location of the site but was used to organise it. Two groups of sixth-century graves were positioned on opposite sides of the barrow, surrounding it and reinforcing the physical separation of these 

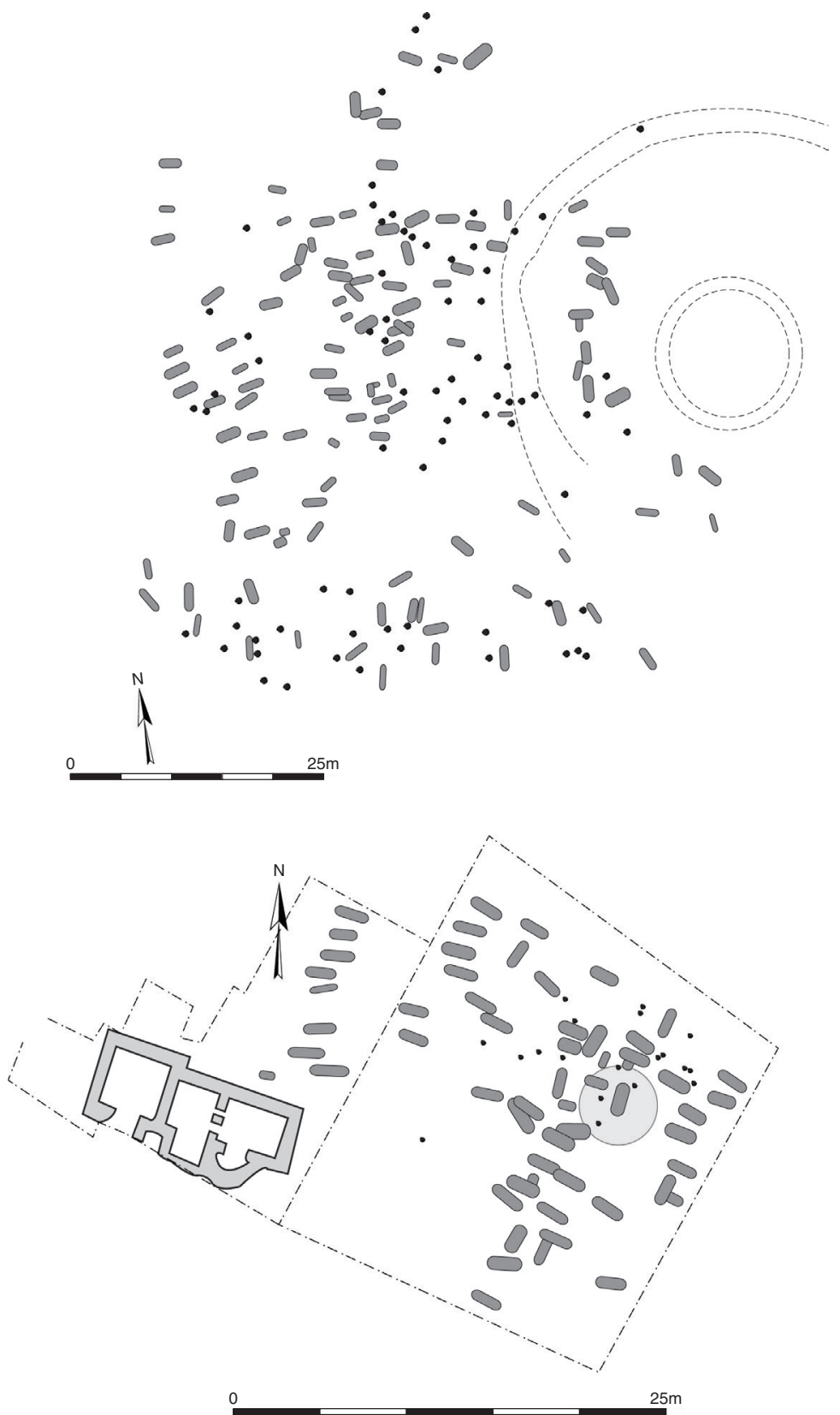

Figure 2.1 Early Anglo-Saxon cemeteries at Orpington, Kent, and Abingdon, Oxfordshire. The Abingdon cemetery (top) was deliberately located next to a Bronze Age barrow and made use of the barrow ditch in its organisation. Orpington (bottom) was located to the west of a Roman building, presumably visible when the cemetery location was chosen. 


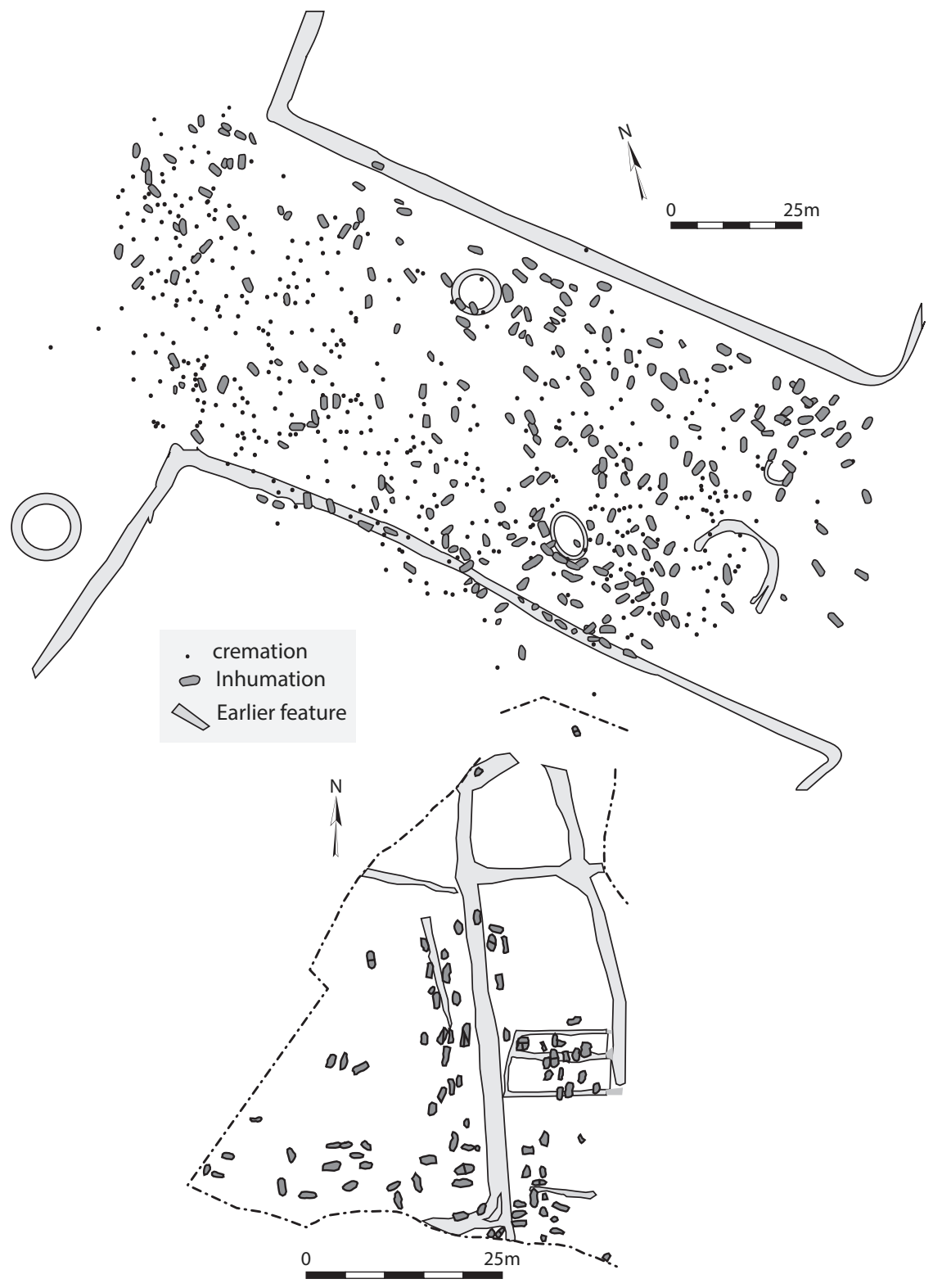

Figure 2.2 Mucking II, Essex (top), was a large and complex mixed-rite cemetery. The graves were positioned in between two late Roman ditches, which then shaped the cemetery. Berinsfield, Oxfordshire (bottom), also used a series of Roman ditches to provide structure; graves were adjacent to a N/S- or E/W-oriented ditch, and some were located within a small enclosed area. 
two plots. The early Anglo-Saxon cemetery at Saltwood, Kent, was also divided between two Bronze-Age barrows, over $100 \mathrm{~m}$ apart, and the two groups of seventh-century burials at Caistor St Edmund, Norfolk, were separated by over $150 \mathrm{~m}$ and focused on two separate ring ditches (Penn, 2000). The ring ditches at the cemetery at Springfield Lyons, Essex, contained part of the site and housed a section of the cemetery whose ritual treatment was different to many of the inhumations found outside the ring ditches (see Chapter 4). Topography was an important part of the early Anglo-Saxon burial syntax. It influenced how people selected a location for their burial ground and continued to influence how that burial ground developed over time and how it was structured, defining similarities between individuals and differences between groups of graves. People created a site by selecting a location, but that location then influenced how they and later generations interacted with that space.

\section{Grave plots}

Of all of the ways to describe cemetery space, the most enduring are accounts of the clustering of graves into visually definable plots. For this study a plot is considered to be a group of graves with a clear demarcation separating it from other groups. Unfortunately, many earlier identifiers of plots have not always been clear about how they arrived at their boundaries. In an early and systematic investigation Ellen-Jane Pader (1982) used multivariate statistical methods to calculate differences between burials by identifying those which were most similar. Based primarily on artefacts and body positions, she was able to offer a detailed description of the organisation of four sites - Holywell Row and Westgarth Gardens, both in Suffolk, Bergh Apton, Norfolk, and Droxford, Hampshire. Mads Ravn (2003), attempted a similar study using serration-based statistics on the inhumation graves at Spong Hill, Norfolk. Unfortunately, he was unable to identify any groups in the inhumation graves, although the patterning he observed among cremation vessels showed far more spatial planning around age and gender than independent clusters of men, women and children (Ravn, 2003: 99-129).

These two different statistical methods were used by Pader and Ravn to investigate the content of graves and derive similarities, although Ravn implied that there was simply too much variation in the mortuary rite to identify meaningful similarities. Other scholars have shied away from computer methods and have relied on the visual appearance of a cemetery, with or without considering the content of individual graves, to conclude that cemeteries consisted of single or multiple-grave 
plots (see Chapter 1; Evison, 1987; Hirst, 1985; Stoodley, 1999; Härke, 1992). Alternative studies have used a combination of spatial layout and chronological information to understand or identify plots (Härke, 1995; Penn and Brugmann, 2007).

Just as there have been different methods employed to investigate the organisation of cemetery sites, there have also been two prevailing ways of describing the results. Pader (1982), Evison (1987) and Hirst (1985) preferred to see small clusters of burials as resembling small groups - mother, father and children, for example. Evison took this interpretation further and argued that the clusters of graves at Great Chesterford, Essex, were defined by large barrows overlying each of them (Evison, 1994: 46). In contrast, Heinrich Härke (1997), Nick Stoodley (1999) and Kenneth Penn and Birte Brugmann (2007), preferred to see larger, mixed burial plots that contained multiple adult inhumations. However, these two explanations are not always contradictory and Stoodley happily divided the Norton cemetery (Cleveland) into four small units based on the presence of gaps visible between groups of burials (Stoodley, 2011).

Recent developments in spatial analysis computer software particularly spatially descriptive statistics and GIS (geographic information systems) - have made different types of statistical assessment possible. For example, Ripley's K-function analysis can be used to identify deviations from spatial homogeneity: the distance at which there is statistical significance in the proximity of groups of graves. This function can be used to investigate the mathematical evidence for clustering within a cemetery (Sayer and Wienhold, 2012). ${ }^{1}$ Ripley's K-function provides statistical proof of clustering at multiple scales in graphical form, and provides a numerical distance between points at which clustering occurs. These distances can then be imaged as heat maps or kernel density plans which illustrate the density of burial by asking the computer to draw a heat map based on the value provided from the Ripley's K-function. Once established, this approach can be used to identify the size and extent of groups of graves within a cemetery, as the kernels plotted over a grave will overlap where there is statistically significant clustering. It is also useful to establish the presence of significant gaps around graves which may have hosted small barrows (see Chapter 4).

Burial plots can be identified in many different ways and scholars have focused variously on the presence of children's graves, the similarity of objects or the identification of groups of graves. ${ }^{2}$ What the statistical assessment demonstrates is that there is, for numerous sites, significance in the grouping of some graves into clusters and that these were used in the arrangement of cemetery space. One of the key characteristics of the cemeteries described here is the variety of significant 
distances between burials. At Lechlade and Berinsfield, for example, the difference in the density of graves was itself a key difference between the sixth- and seventh-century burials (Sayer and Wienhold, 2012), and at other sites the density of each plot was a significant visual identifier used to differentiate between them. Grave plots were an important tool in organising early Anglo-Saxon cemeteries, but even these vary noticeably, both between and within sites. Variable characteristics of plots include their density, date and shape.

One cemetery which is divided into three noticeably distinct plots is Wakerley, Northamptonshire; it consisted of eighty-five excavated skeletons in seventy-two graves and it dates to the sixth century AD. When the cemetery was excavated in 1968 and 1969, the excavators visually identified three major groups of burials: a western group, a central group and an eastern group (Adams and Jackson, 1988-9: 74-5). Re-analysis using the Ripley K-function showed statistically significant clustering among graves at approximately $3 \mathrm{~m}$. When the density of graves was plotted at this distance, it showed three groups of burials: a large group to the east (C), a central cluster (B), and a less dense south-western cluster (A) (Figure 2.3). The gaps between plots can be identified because Ripley's L-function tells us how big they need to be to vary from homogeneity, in other words, the gap between the end of one cluster and the beginning of another. However, people at the time did not always make decisions which can be shown now in statistically meaningful ways and, as if to prove this, there is a small grave (grave 72 ) situated between the central (B) and western (A) plots at Wakerley. The grave sits on the midpoint between the two clusters and is more than $3 \mathrm{~m}$ from each. Grave 72 was intentionally located in this 'in-between area', positioned deliberately at odds with the cemetery's dominant arrangement.

The cemetery at Norton, in northern Cleveland, excavated between 1983 and 1985, is like Wakerley in that it was organised into deliberately separated groups of graves. However, these plots are much less dense and notably less distinct than those seen at Wakerley. The Norton site is a large Anglo-Saxon cemetery which consisted of three cremations and 117 inhumation graves, dating predominantly from the sixth century, but with a small number of graves from the early seventh century. The excavators suggested that it was laid out in rows rather than plots, and these were divided into two visible halves by a wide gap along the cemetery's central axis (Sherlock and Welch, 1992: 15). Nick Stoodley (2011: 654) preferred to interpret the whole site as consisting of four smaller plots, based on the appearance of groups of children's graves within these areas. The proximity of burials was statistically significant at $7 \mathrm{~m}$, appreciably sparser than at Wakerley. The density of graves suggests the presence of two large burial plots separated by the central 

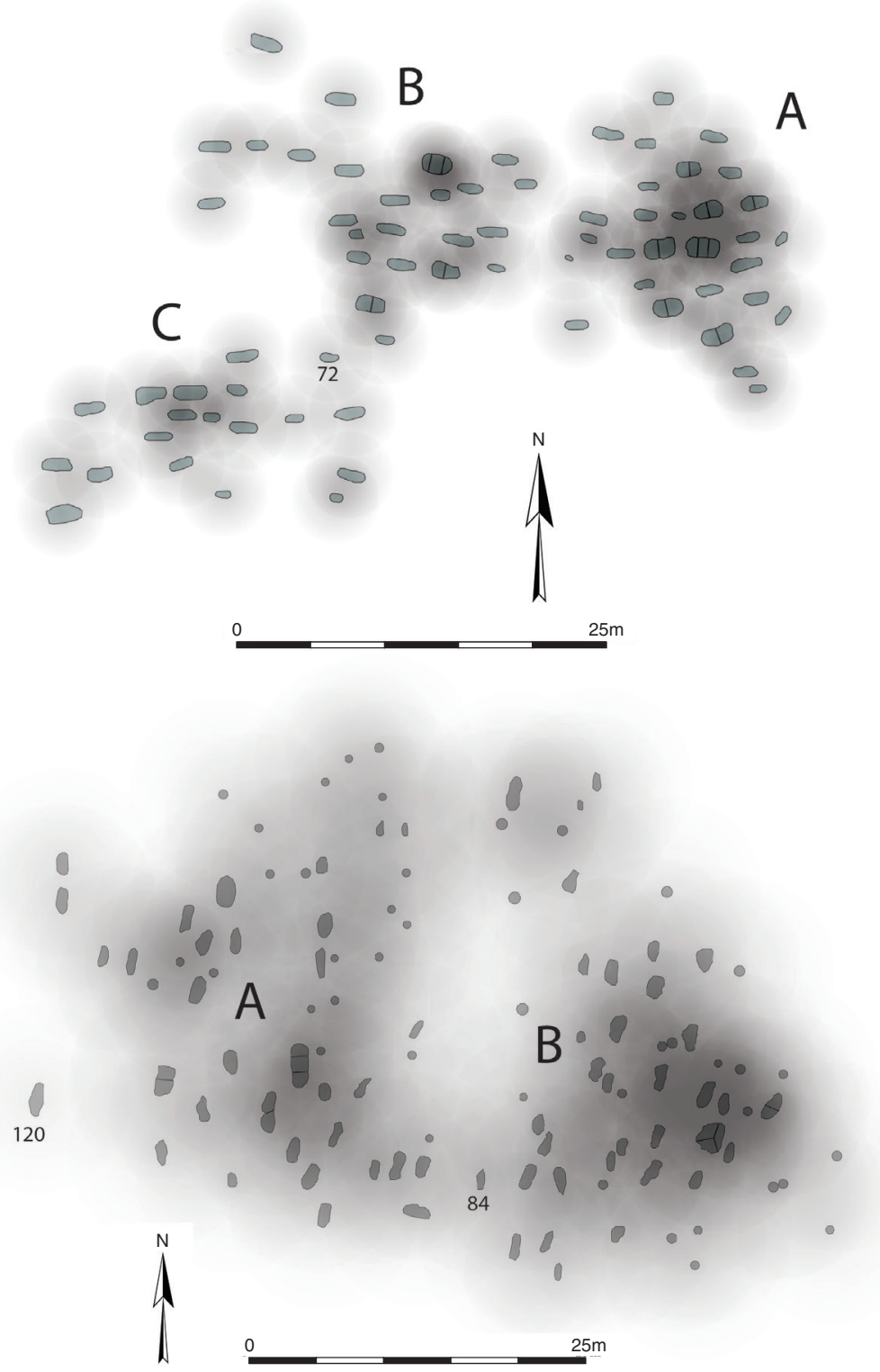

Figure 2.3 Wakerley, Northamptonshire (top) was divided into three groups of graves, $\mathrm{A}$ to the west, $\mathrm{B}$ in the middle and $\mathrm{C}$ to the east. Grave 72 was located in between plots $\mathrm{B}$ and $\mathrm{C}$ and over $3 \mathrm{~m}$ from burials in either plot. Norton, northern Cleveland (bottom), was divided into two groups, A to the west and B to the east. Grave 120 was on the western edge and grave 84 was placed in between the two plots. 
gap, with each of these two plots denser in its interior than around its edges (Figure 2.3). Each of these two groups is roughly the same size and, by eye, there appears to be a separate group to the north of plot $\mathrm{B}$, but these are within $7 \mathrm{~m}$ of the other inhumations in this area. There is just one outlying grave to the west of plot A (grave 120) but, as with Wakerley, the pattern has been challenged by just one grave (grave 84 ) placed deliberately part way between plots A and B.

The Wakerley and Norton cemeteries were divided into two or three groups of roughly equal proportions, but this is not always the case, as can be seen in the cemetery at Orpington which was described in Chapter 1 . Orpington was a mixed-rite cemetery and consisted of eightyfive burials in eighty separate graves, excavated in stages between 1965 and 1977 (Tester, 1968; 1969; 1977; Evison, 1987: 164). The clustering of graves was statistically significant at $2.5 \mathrm{~m}$ (Figure 2.4). This cemetery seems to have been divided into two unequal but spatially distinct parts: a small group of nine graves on the west (B) and the remaining graves to the east (A), with a concentration of graves around the barrow burial, grave 23. Two inhumation graves and some cremations were placed well away from the plots in between them and not associated with either. Just like the graves at Norton and Wakerley, these burials were deliberately positioned in an indistinct location.

Similarly, the early Anglo-Saxon cemetery found at Blacknall Field, near Pewsey in Wiltshire, consisted of unequal groups of graves, with two large plots of similar size and two provably smaller but dissimilar ones in between. Blacknall Field dates to between the late fifth and midsixth centuries AD (Annable and Eagles, 2010). The site contained over 102 skeletons and four cremations from one hundred excavated graves. It was explored in stages between 1968 and 1976. The graves clustered with statistical significance at $3.5 \mathrm{~m}$, with the two large plots in the north (A) and south (B) purposely separated by over $20 \mathrm{~m}$ (Figure 2.4). In between these were found two smaller and less dense groups of graves $(\mathrm{C}$ and $\mathrm{D})$. Although parts of plot $\mathrm{D}$ remain unexcavated, its density suggests a smaller cluster of graves. Interestingly, the larger northern A and southern B plots had been constructed with similar densities and both clusters also included a number of solo satellite graves on their outer peripheries.

Despite these examples, not all early Anglo-Saxon cemeteries were deliberately separated into statistically significant groups of graves. The small site at Snell's Corner, Hampshire, contained thirty-two graves in one large group. Härke (1992: 171; 1997: 138) described Snell's Corner as monocentred and the Ripley K-test agreed, showing spatial homogeneity because deliberate gaps could not be found (Figure 2.5). Similarly, the forty-four graves at Winnall II, Hampshire, were not statistically 


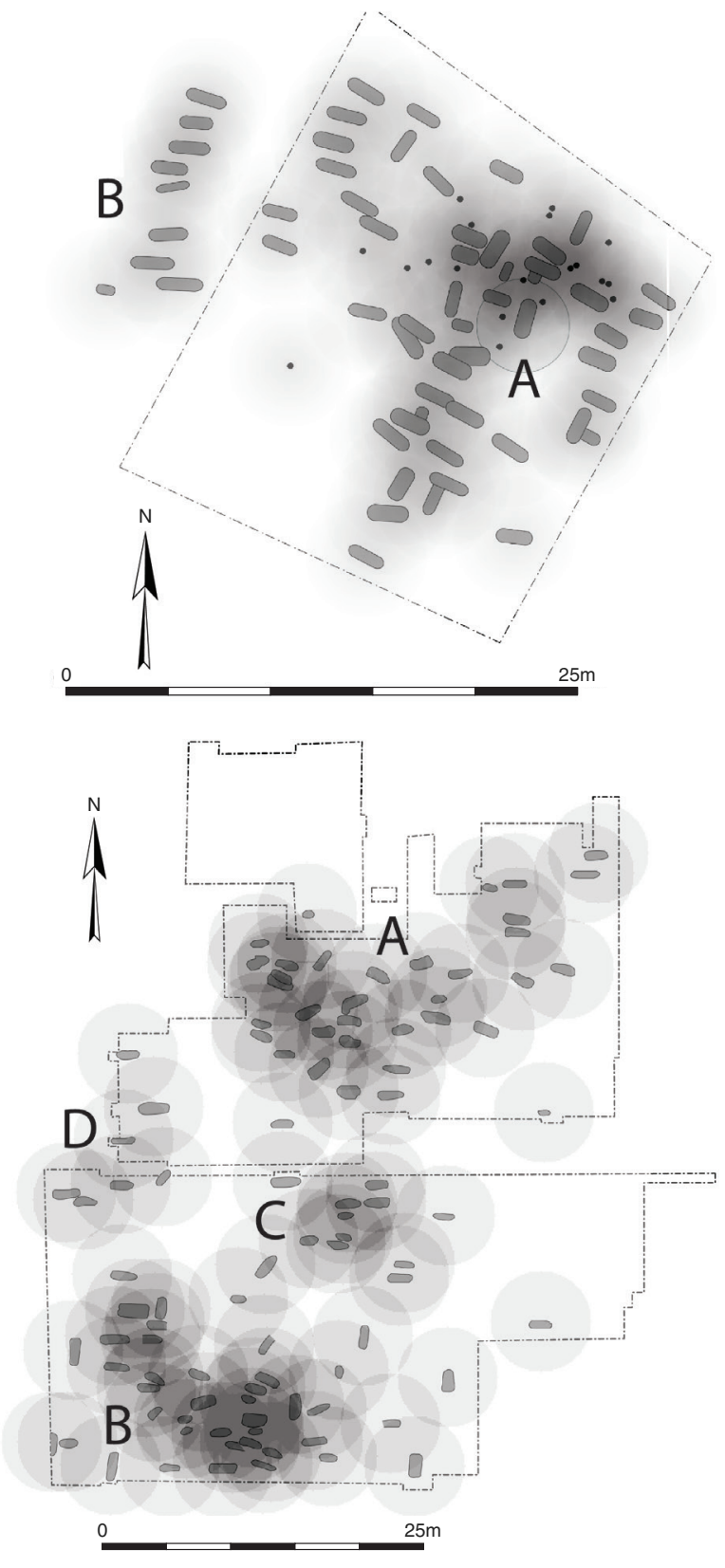

Figure 2.4 Orpington, Kent (top), consisted of two groups of graves, A to the east with the majority of burials, and nine others to the west in group B. Blacknall Field, Wiltshire (bottom), was divided into at least three plots, A to the north, B to the south and C, a small plot, in the middle. There was a further group of graves, $\mathrm{D}$, to the west, which may have been a further plot, as yet unexcavated. 

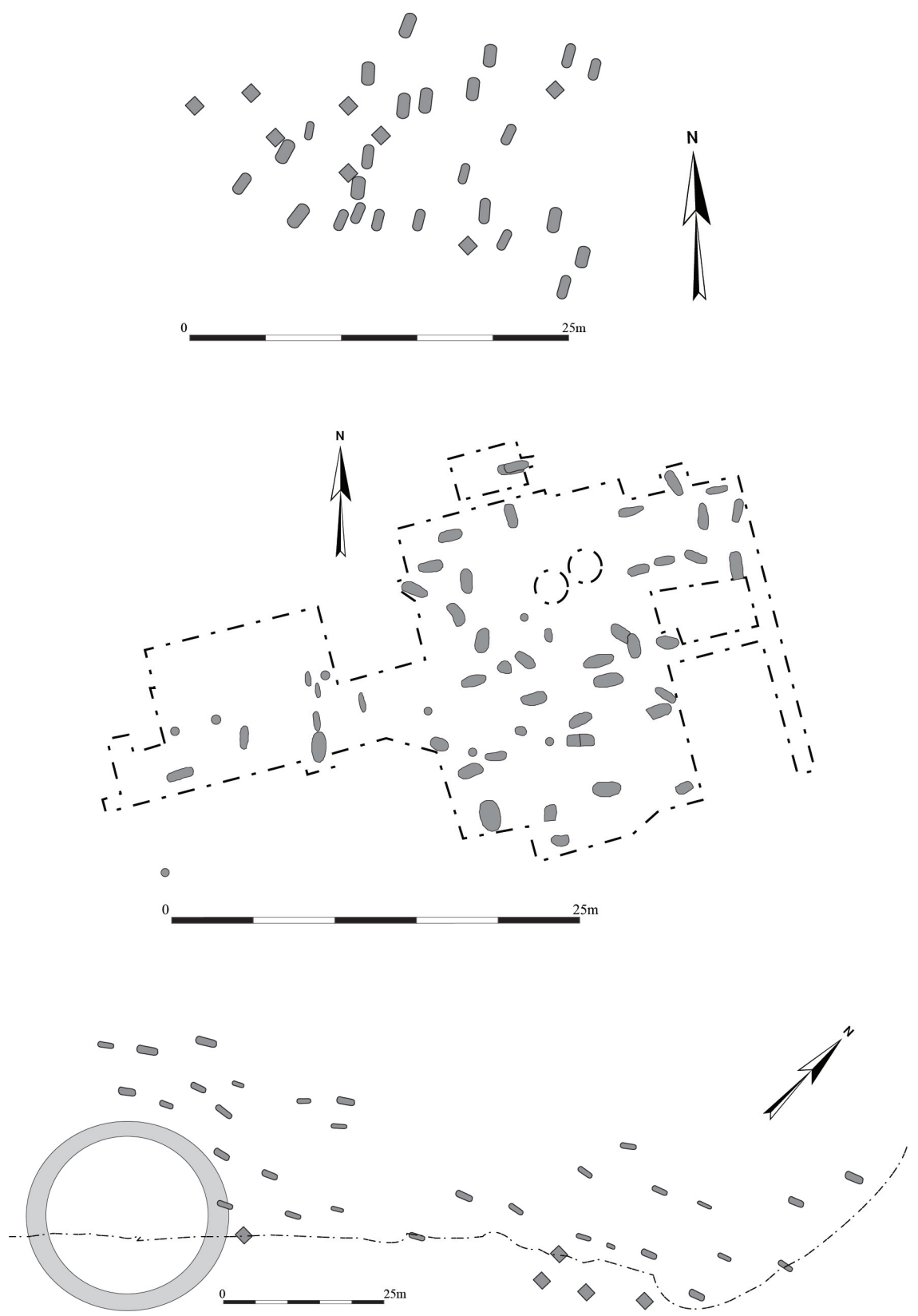

Figure 2.5 Snells Corner, Hampshire (top), consisted of one group of graves. Sewerby, East Yorkshire (middle), gave the impression of multiple plots but was homogeneous, although the excavated area may have been a small part of a larger cemetery. Holborough, Kent (bottom), looked like two groups of graves but in fact was entirely homogeneous. 
clustered, and neither were the fifty-seven fifth- and sixth-century graves from Sewerby in the East Riding of Yorkshire (Hirst, 1985). The Sewerby cemetery highlights an important point here, because the graves were dispersed and could give the impression of multiple plots (see Stoodley, 1999: 131-4; Härke, 1992: 171; 1997: 138). Perhaps the site which is most surprising in its homogeneity, with no evident clustering, is the cemetery adjacent to an older ring ditch at Holborough, Kent. Although only partially excavated, these thirty-five graves were widely spaced and filled an area approximately $115 \mathrm{~m}$ long and $38 \mathrm{~m}$ wide. This is surprising because to the naked eye Holborough looks as if it had two clusters of graves, but in fact burials are spaced evenly throughout the burial area. The deliberateness of this spacing is particularly apparent when it is contrasted with the dense 374-grave cemetery at Morning Thorpe, which was found in a much smaller area than Holborough, just $75 \mathrm{~m}$ by $26 \mathrm{~m}$ (Green et al., 1987).

Unfortunately, early Anglo-Saxon cemeteries cannot be described simply as either grouped into plots or dispersed. The cemeteries at Polhill and Deal, both in Kent, are particularly interesting because they combine two characteristics, where part of each cemetery was clustered unevenly and part was regularly dispersed. Polhill is a predominantly seventh- and eighth-century site, and importantly the main cemetery was subdivided into two groups of graves which were clustered at $5 \mathrm{~m}$, (A) and (B), with a small satellite group to the south of the main cemetery (C) (Figure 2.6). The southern part of the main group (A) of graves was the larger of the two clusters and interestingly to the north of these was placed a deliberately homogeneous group of thirty-seven graves spread over an area of approximately $75 \mathrm{~m}$ by $70 \mathrm{~m}(\mathrm{D})$.

The dispersed graves at Polhill, Snell's Corner, Winnall II and Holborough are all seventh- or eighth-century cemeteries. It may be that all of these graves had small barrows erected over them, but this seems unlikely. Perhaps the later-sixth and seventh centuries saw a deliberate transformation in the burial rite, but also in the stimuli which structured that rite. For many communities, clustered graves were no longer an important part of the funerary message.

\section{Grave density}

Grave density is a characteristic of cemetery organisation tangled up with the construction of identifiable grave plots. Density is a powerful visual tool that may have been used to enhance physical proximity or difference. This is evident in two ways: firstly, different cemeteries display different densities of graves; and secondly, within some sites the density of graves varies between groups and may have been used 


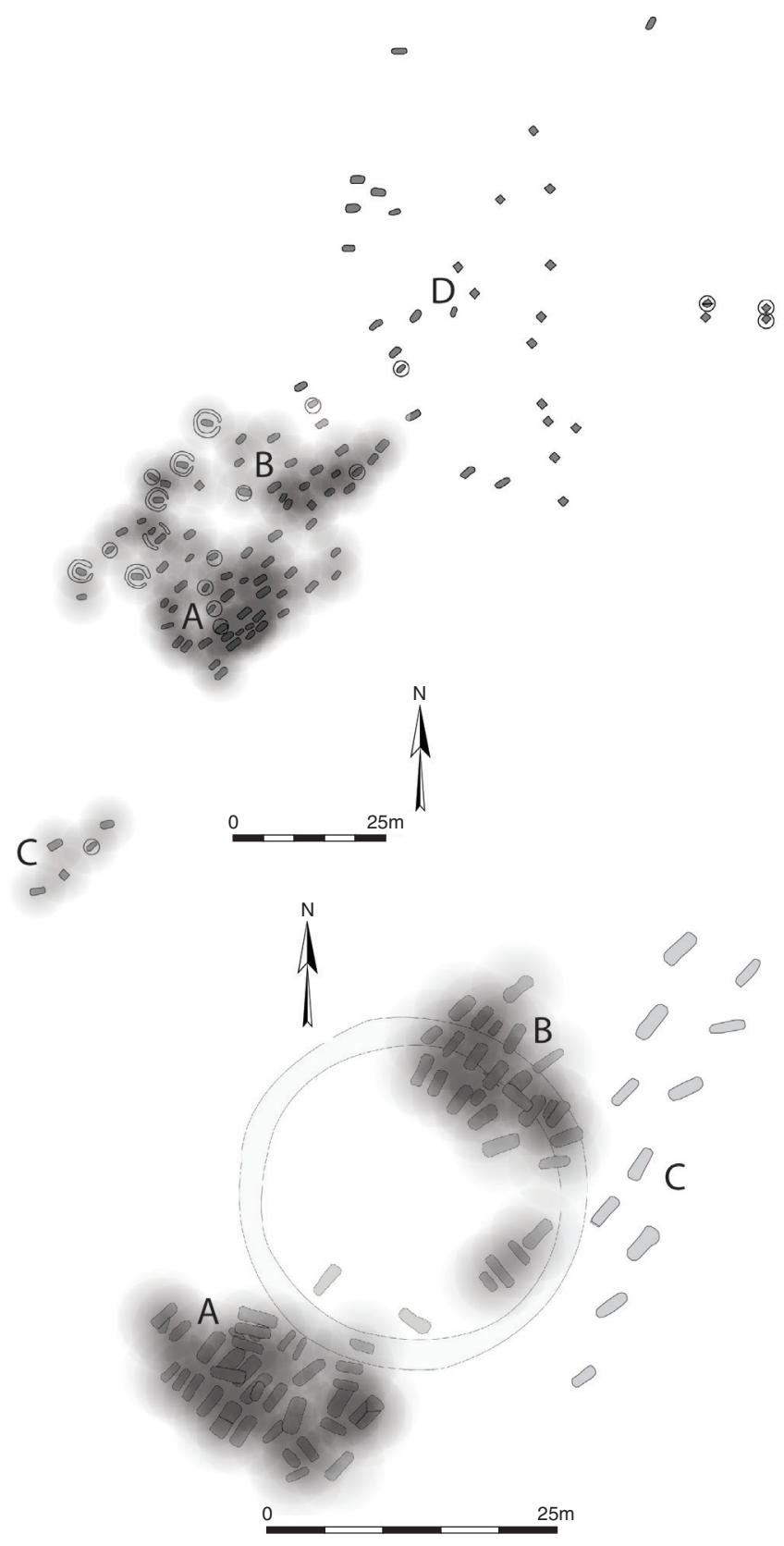

Figure 2.6 Polhill (top) and Deal (bottom) in Kent had different internal organisations. Polhill consisted of three groups of graves A, B and C. Two of these were in close proximity, $\mathrm{A}$ and $\mathrm{B}$, and a number of inhumations were deliberately dispersed (D). Deal was similarly organised with two plots, A and B; the later graves were homogeneous $(\mathrm{C})$. 
to distinguish clustered grave plots and ungrouped graves. As we have seen above, the density of graves is closely related to the clustering of graves. For example, the Polhill cemetery was divided into two clustered groups of graves with a number of dispersed burials to the north and these graves were much less densely spaced than the clustered burials (see Figure 2.6). The site at Deal, by contrast, has a similar arrangement, but the groups are much more clearly defined and distinct (Figure 2.6). The cemetery was excavated between 1986 and 1989 and revealed seventy-six closely packed graves, divided into three plots. There were two tightly clustered groups of fifth- and sixth-century burials, one to the north and one to the south of a Bronze-Age ring ditch, (A) and (B) respectively, and these graves clustered at $5 \mathrm{~m}$. To the east of these was a third, more homogeneous, group of less dense graves $(\mathrm{C})$, placed more than $5 \mathrm{~m}$ apart. The difference was evidently deliberate and these graves were part of a second phase in the burial ritual: this new generation deliberately changed the burial ritual, rejecting the previous burial areas in favour of a new zone and a new organisation. Indeed, these newer graves of the later sixth century and the seventh century may have had small barrows constructed over them (Sayer, 2009). Nonetheless, these funeral organisers deliberately maintained the cemetery as a single burial site which highlighted the new burial form while maintaining their connection with the past through physical proximity.

In both the Deal and Polhill cemeteries, the density of the burials was related directly to the use or nature of grave plots: at Polhill the two plots contained the densest groups of graves and at Deal the density of burials was part of a chronologically specific burial practice. However, at sites with less well-defined plots of graves, the density of burial may have been the defining organisational principle. An example of this can be found with the large cemetery at Mucking, which showed significant clustering at $2 \mathrm{~m}$, but with a few gaps between burial groups. However, the relative proximity of graves may have distinguished different groups of burials with dense areas in the south (A), west (C) and north (D), and less dense groups in the middle (B) and east (E) (Figure 2.7). Equally, there were no evident plots at Morning Thorpe, where the site was particularly densely packed, with significant clustering at $1.5 \mathrm{~m}$. Notably, Morning Thorpe was organised into a series of groups of graves centred on two high-density areas in the centre of the site, areas A and B.

The use of contrasting burial density is particularly evident at West Heslerton, where grave proximity was employed differently between the burial plots (Figure 2.8). This large inhumation cemetery of 201 graves was discovered in 1977 and excavated between 1977 and 1987. West Heslerton was divided up into plots, two of which - to the south of the site $(\mathrm{A}$ and $\mathrm{B})$ - clustered at around $2.5 \mathrm{~m}$ and were found within 

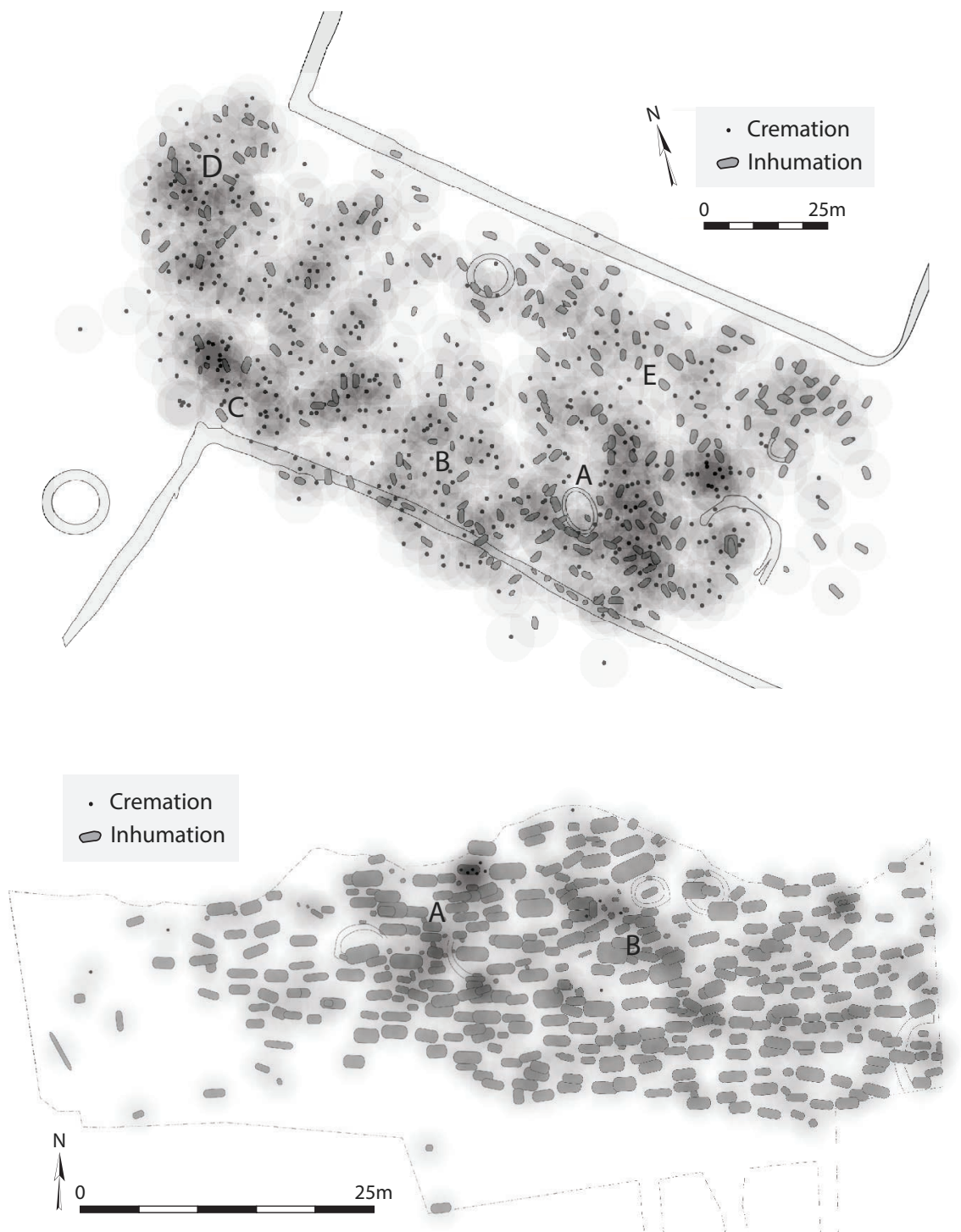

Figure 2.7 Mucking II, Essex (top), was a large and complex cemetery. The graves seem to have been organised into a series of large groups: A, C and D were dense clusters, and B and E were less dense. Morning Thorpe, Norfolk (bottom), did not have identifiable plots with gaps, but there were two particularly dense areas of graves (labelled A and B). 


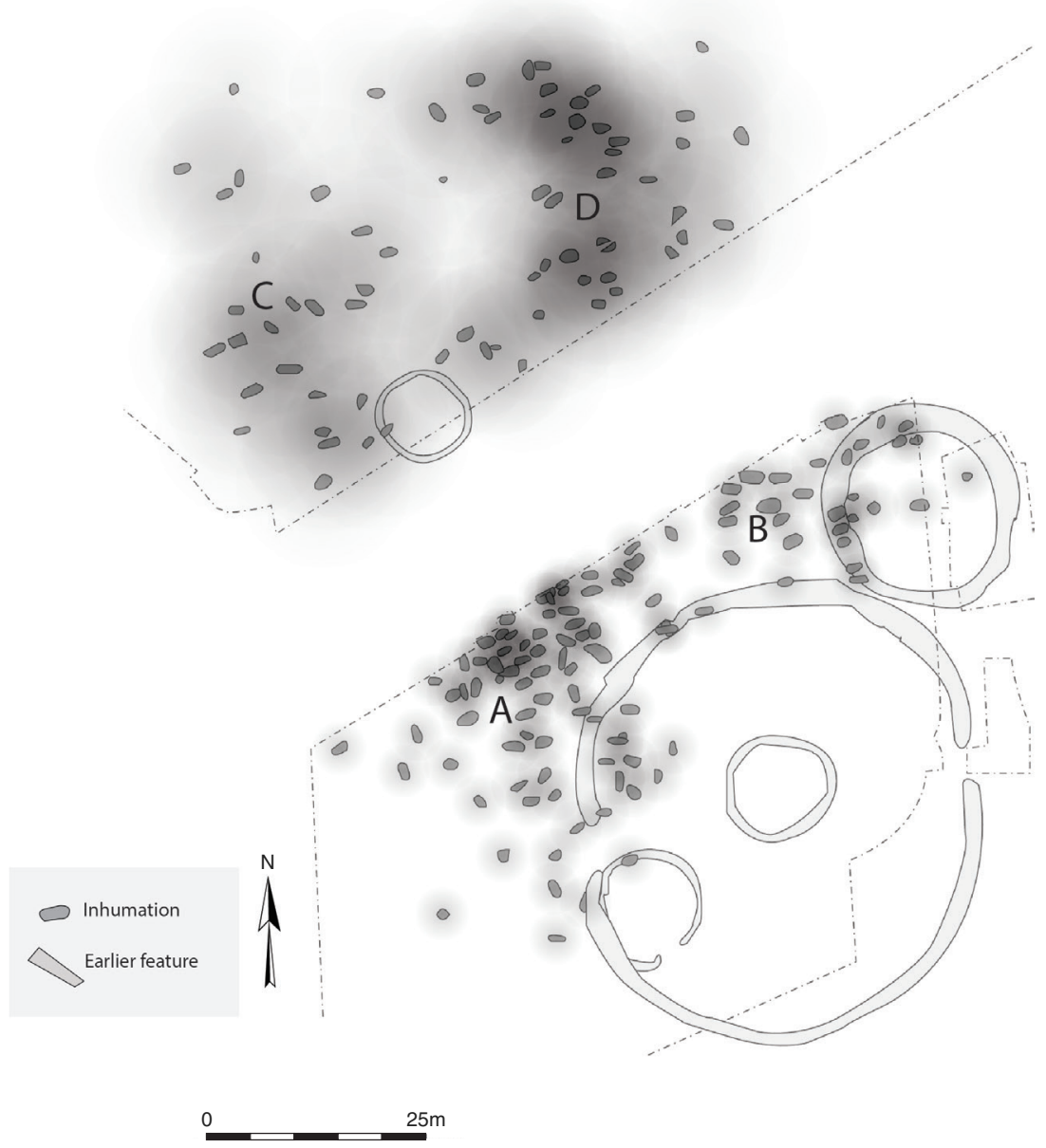

Figure 2.8 West Heslerton, East Yorkshire, had four plots A-D. The two southern ones (A and B) were densely packed at $2.5 \mathrm{~m}$, the two northern plots $(\mathrm{C}$ and $\mathrm{D})$ were less dense, with clustering at $10 \mathrm{~m}$.

different areas of a complex of ring ditches; A being to the north-west of the large ring ditch, and B lying between the large ring ditch and a smaller one to the north-east. To the north of the modern road was found a much less dense group of burials with statistical clustering at $10 \mathrm{~m}$. This group of burials seemed to be divided into two different groups, one on the east of a small ring ditch and one to the west. Both plots extended to the north, leaving a gap of between $11 \mathrm{~m}$ and $15 \mathrm{~m}$ in between. The spatial zoning of the four burial plots at West Heslerton differed, and funerary decisions may have focused on where and how to place the dead in a way that distinguished these different groups of individuals. 
Similar difference can be seen at Dover Buckland, Kent; this large cemetery was subdivided into multiple plots or groups of graves and, like West Heslerton, these groups of graves had different densities in the north and south of the site. The Dover Buckland cemetery was first excavated in 1951 and again in 1994, and the sites of these excavations were separated by a railway, which had destroyed a limited number of graves (Parfitt and Anderson, 2012: 6). Together the two excavated elements included about 507 graves. Fascinatingly, these two elements (north and south) were organised in very different ways. The south-westernmost part of the cemetery, excavated in 1994, consisted of seven plots of graves all neatly separated and consistently clustered at $2 \mathrm{~m}$ (Figure 2.9). The 1951 graves in the north-east were clustered at different densities. Two groups of graves were most densely clustered at $3 \mathrm{~m}$ and one of these areas on the north of the site appears to have been divided into two plots, one larger one to the west (A) and one small one to the east (B). The other tightly spaced group, with a $3 \mathrm{~m}$ cluster, was found to the north-east of the 1951 excavation adjacent to an earlier ring ditch (C). However, the majority of graves were located between these two dense areas and have a less dense clustering at $9 \mathrm{~m}$. These more dispersed graves seem to have been arranged into a series of smaller groups or plots. To the south-east of these areas the graves were placed homogeneously, but unfortunately this area was only partially excavated and so its extent and population is impossible to determine.

At Polhill, Deal, Mucking, West Heslerton and Dover Buckland, different funerary decisions were made which led to the varied organisation of these sites. This is compounded because there would have been dissimilar influences among funerary agents creating a contrasting use of space. Grouping graves together, or spreading them out, may have served as a way to create connections and mark difference within the mortuary environment. Grave density was used alongside other organisational characteristics like plots and created a rich and varied funerary aesthetic. Ultimately, this employment of space and differences in the origination of burial rituals led to the variations seen at these sites. At Deal, this was chronological: the last generations to use the site considered how that space had been used by its predecessors and opted for a different visual aesthetic. At West Heslerton and Mucking the variation existed between contrasting but contemporary groups. Perhaps burial practice differed because there were multiple strands to the burial tradition passed on between different community groups. Notably, at Polhill and Deal the least dense areas were not clustered at all, but there may have been very different reasons for this. At Deal, these later burials were among the wealthiest, whereas at Polhill few artefacts were associated with the more dispersed graves. 

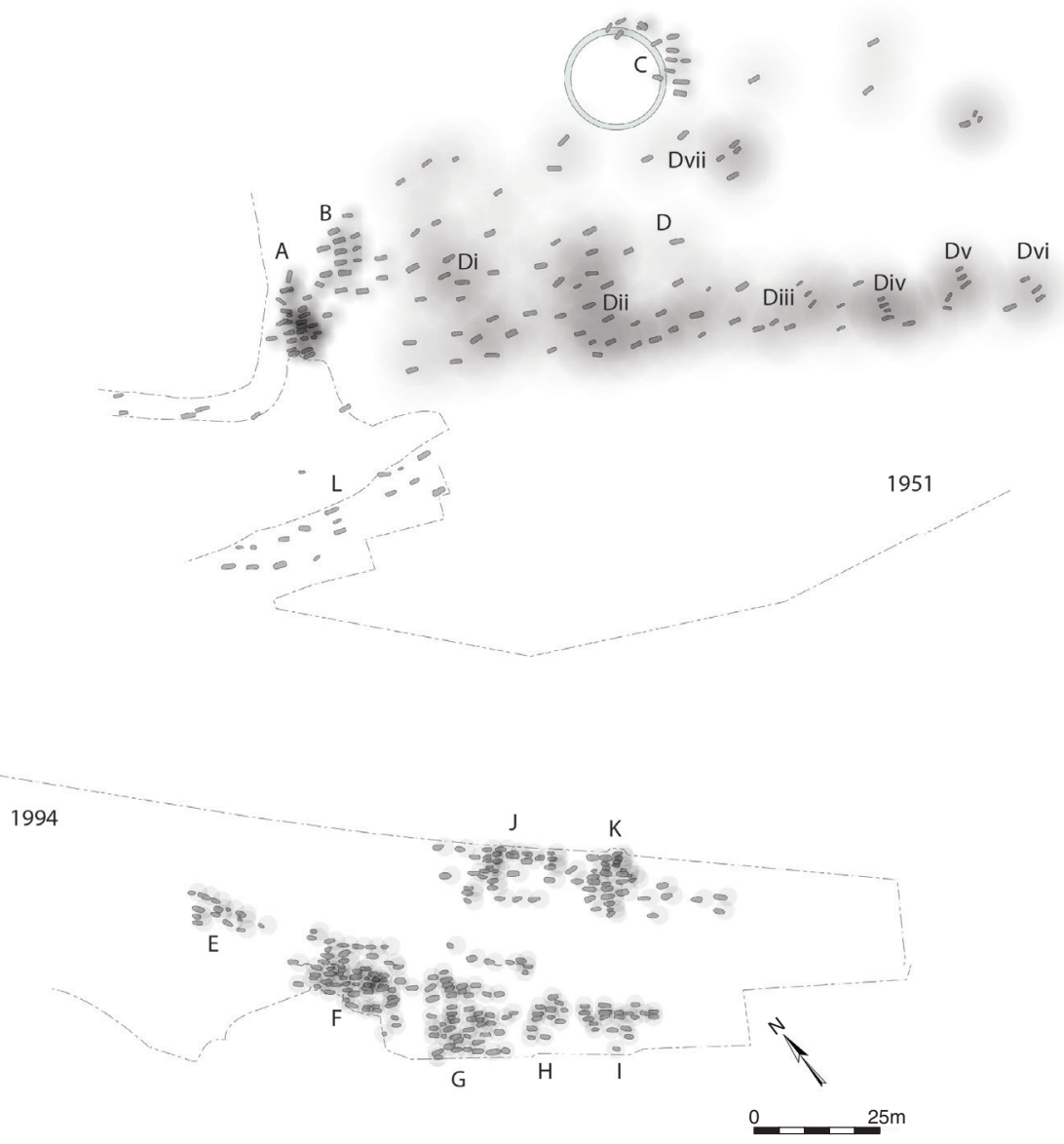

Figure 2.9 Buckland, at Dover in Kent, was a very complex mortuary landscape with multiple plots and different densities of burial. The part of the cemetery excavated in 1994 consisted of seven identifiable plots clustered at $2 \mathrm{~m}$ and with clear gaps between them. The north-eastern part, excavated in 1951, consisted of three plots (A, B and C) clustered at $3 \mathrm{~m}$, and zone D, which consisted of at least seven groups of graves clustered at $9 \mathrm{~m}$. Area L was homogeneous but only partly excavated.

\section{Rows of graves}

Many cemeteries either have rows or appear to be organised into rows or lines of graves. For clarity, rows are considered to be graves that are side-on to each other, whereas lines are lined up head to toe. Cemeteries organised in this way are seen more often in France and Germany, and date to the Iron Age and Early Middle Ages; they consisted of cemeteries with long rows of graves across them. The temptation is to assume that 
burials started at one end and were placed in chronological order until a particular row was finished and a new one started, a pattern reminiscent of some nineteenth-century practice (Sayer, 2011: 205). ${ }^{3}$ However, this is not supported by the archaeological evidence, and adjacent burials can be chronologically separated by several decades or even hundreds of years (Hakenbeck, 2007a; 2011; Stapel, 2007). Rows of graves would not have been a series of neat lines when the cemetery was in use, even if they may seem that way to archaeologists looking at a cemetery plan. In many continental cemeteries, like Junkersdorf, Bülach, Müngersdorf (all near Cologne, Germany), or Lavoye or Le Haie des Vaches, in northern France, that appear to be organised in rows, there are clusters of wealthy graves in particular zones of the site and individual wealthy burials may have been located in clusters across several rows (Halsall, 1995b: 131; Christlein, 1973: 163-4).

A number of early Anglo-Saxon cemeteries contained rows - for example, Lechlade, St Peters (Kent), Orpington and Springhead (Northfleet, Kent). Few were true row-grave cemeteries, however, and these examples contained a single row (Lechlade) or a small group of rows (St Peters) in an otherwise non-linear cemetery pattern. Other sites like Norton, Cleveland (see below), did not contain any convincing rows, but instead displayed irregular lines of chronologically disparate burials which gave the impression of rows when looked at in their totality - a view that would not have been shared by the cemetery's users. One of the exceptions is Garton Slack II, East Yorkshire, which consisted of loosely defined lines organised into two clusters of twenty-nine and thirty-two burials, separated by a gap of $14 \mathrm{~m}$ (Figure 2.10; Mortimer, 1905: 247-57). Garton Slack II was a later cemetery and seems to have inherited its location and structure from its proximity to earlier ditches (Lucy, 2000a: 128). Another exception is the row-grave site at Marina Drive in Dunstable, Bedfordshire, which consisted of a cemetery organised into three rows. In two of the rows, the burials (nine and thirteen respectively) were N/S oriented, whereas the third group of burials, to the east, had ten burials aligned E/W (Matthews, 1962). The artefacts from Dunstable included a broad seax and a needle box, indicating that this site, like Garton Slack II and Springhead, dated to the seventh century and the end of the furnished burial rite, but the graves from Dunstable were probably later graves in a larger cemetery, not dissimilar to the two lines of graves from plot C, Deal.

In England, true row-grave cemeteries are often small and late in date, and individual burials within them cannot be dated easily because they contain few artefacts. They are part of a distinctive late sixthto eighth-century phase of cemetery organisation. Garton Slack II and Springhead are similar to Street House, north-eastern Yorkshire, a 

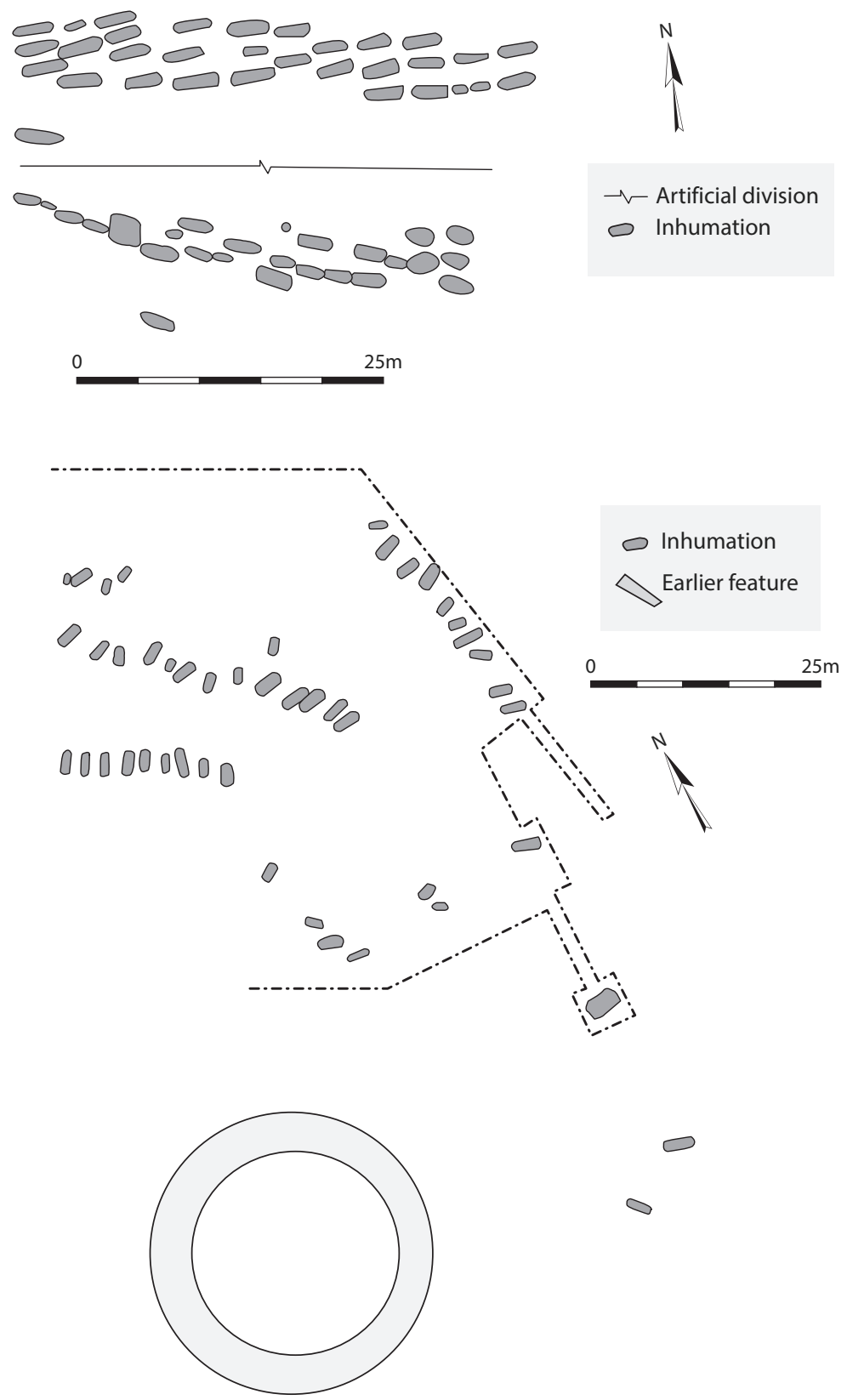

Figure 2.10 Garton Slack II, East Yorkshire (top), and Dunstable, Bedfordshire (bottom), are two examples of row-grave cemeteries. Garton Slack II consisted of two parts, separated by some distance, and Dunstable included three rows. The additional non-row graves at Dunstable, to the south, as well as the Bronze Age ring ditch, are evidence of an earlier and differently organised part of the cemetery. 


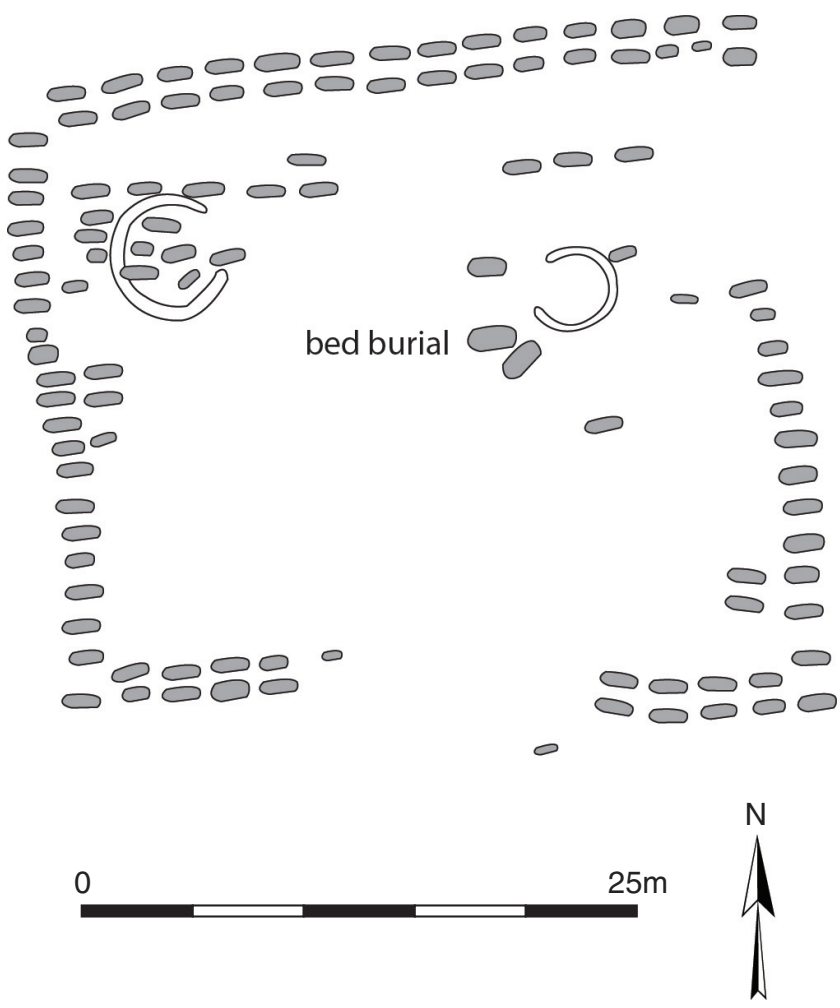

Figure 2.11 Street House, North Yorkshire, was a unique cemetery. A central bed burial, or small group of burials, was surrounded by a series of rows and lines of graves which formed a sub-rectangular shape.

site in which a series of graves was deliberately placed to construct a quadrilateral shape around a central mound and the bed burial (Figure 2.11; Sherlock, 2012). In many ways Street House is similar to many sixth-century cemeteries where graves are positioned in relation to a significant individual, but its deliberate and structured layout places it within a wider Merovingian tradition (for example Dortmund-Wickede, Germany; Stapel, 2007). In plain view, rows and lines of graves look very neat, and this organisation may have been utilised as part of a Merovingian tradition designed to create the impression of an ordered mortuary space, derived from an ordered hierarchical society. Even recognisable continental row-grave sites like Dortmund-Wickede would have looked that way only towards the end of their use (Stapel, 2007). Street House was deliberately conceived and constructed in a very short time and it was probably meant as a tribute for a royal dynasty (Sherlock, 2012). 
Most grave cuts are roughly oblong in plan and so rows are a good and logical way to tightly cluster burials to the same orientation and prevent them from damaging older graves when dug. Rows are a useful strategy employed in the management of cemeteries over time and, at sites like Junkersdorf, they were used to create a particular aesthetic, as with the tightly packed, later burial grounds in England and on the Continent. However, individual rows may also have served a specific purpose. For example, along the eastern edge of the Bidford-on-Avon cemetery, Warwickshire (Figure 2.12), a densely packed row of graves (C) seems to have marked the limit of the cemetery, which was otherwise subdivided into two groups by density, plot A and group B, where A was clustered at $3 \mathrm{~m}$ and the northern graves (B) were deliberately spaced over $3 \mathrm{~m}$ apart. Similar rows of graves at Lechlade, Gloucestershire, and Morning Thorpe, Norfolk, seem to have defined the extent of an internal cemetery boundary (Figure 2.12). In the Morning Thorpe example, the line of graves divides a group of graves to the east of the site. At Lechlade, this row bounds a dispersed seventh-century group, dividing it from the main body of the cemetery.

The use of rows in cemeteries remains elusive, but was almost certainly part of a visual tradition. Many later sites, particularly in Kent and Yorkshire, may have used rows to create an aesthetic of order, influenced by Merovingian practice, which implies less flexibility in cemetery use. Such a tradition created an intent to the cemetery plan and this must have been influenced by a single agent - perhaps an influential individual or family. However, rows of graves were also used like a paling, a row of posts, creating a physical barrier which separated otherwise adjacent zones within a cemetery. This last practice is particularly evident in densely packed and complex cemeteries like Lechlade and Morning Thorpe; in these places, space was limited and the location of a grave was significant. The division of space was important in these sites and the row of graves would have taken many burials, and many years to construct. For example, the mortuary paling at Lechlade was not completed until the seventh century when it divided a group of largely unfurnished and dispersed graves from the cemetery proper.

\section{Grave orientation}

The orientation of graves has received considerable attention, especially where there are minor variations in the angles of those graves (Lucy, 2000b: 132). Discussion has focused on several factors, including the time of death - the solar arc model (see Chapter 1) - or as an important identifier in the performance of religion, where Christians were considered E/W oriented and pagans N/S (Rahtz, 1978). The orientation of 


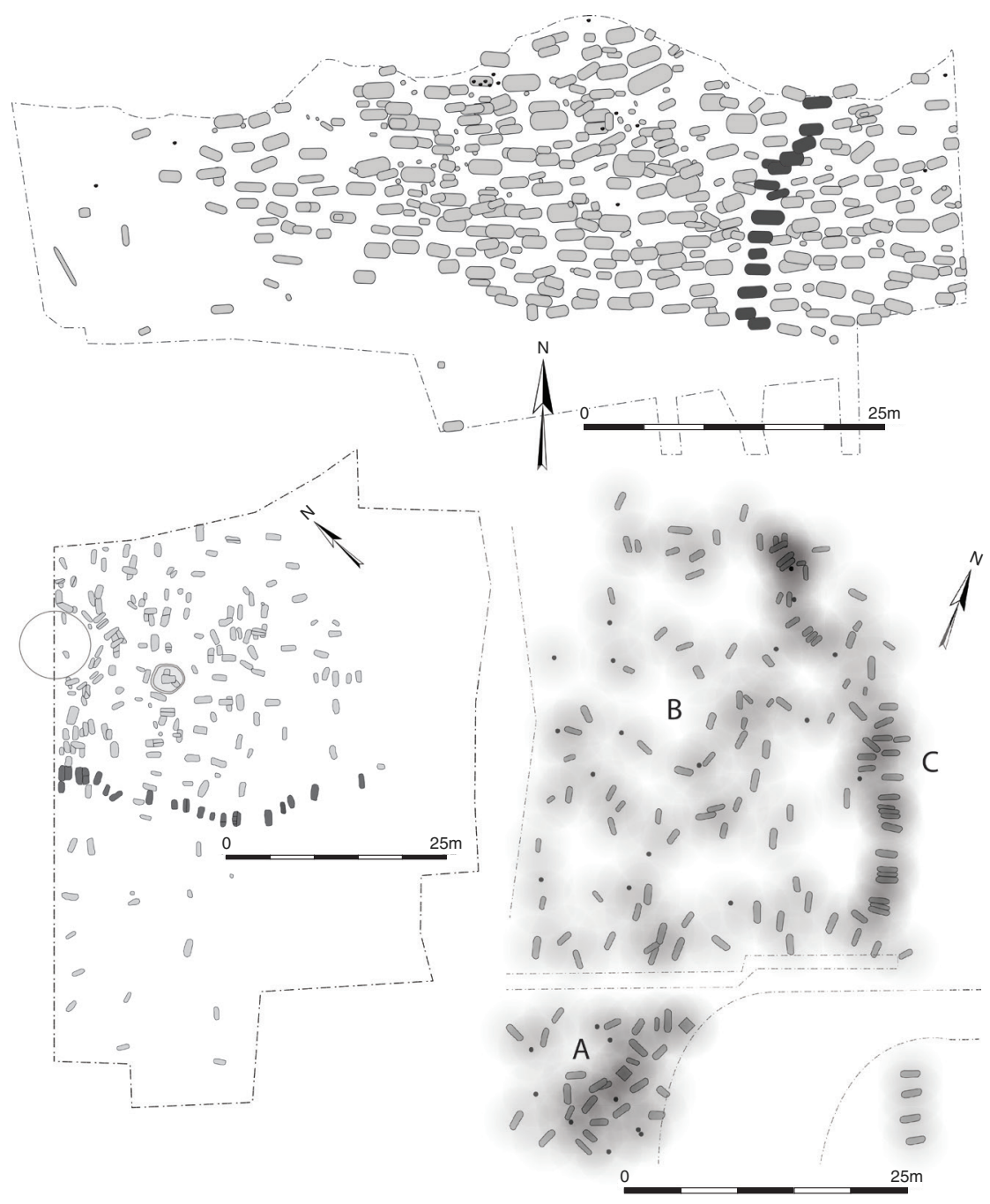

Figure 2.12 Morning Thorpe, Norfolk (top), Lechlade, Gloucestershire (bottom left), and Bidford-on-Avon, Warwickshire (bottom right). In each of these three cemeteries a row of graves may have marked an edge for the cemetery or may have defined a boundary between groups of graves.

a grave has been considered through analysis of the orientation of the body with the head at a particular end, whether the body is crouched or supine, and also more generally using the orientation of the grave. When discussing individual burials, the position of bodies and the orientation of heads may be important; however, in the wider context of cemetery organisation, it may not be particularly informative since the above 
ground circumstances may not distinguish body positions. Even though graves would have been marked in some way, only the archaeologist can see the position within a cemetery of each body, and each head, because when a site was in use the graves would have been closed. Individual body positions, on a 'reverse' orientation, prone or sitting, may have been a significant way for an individual to be treated at the funeral, but the orientation of a grave E/W, N/S or in between follows a pattern particular to each site. Many cemeteries contained a greater number of $\mathrm{E} / \mathrm{W}$ oriented burials; for example, an $\mathrm{E} / \mathrm{W}$ orientation was dominant at Westgarth Gardens, Bergh Apton and Morning Thorpe, whereas N/S was dominant at Beckford B, Worcestershire (Evison and Hill 1996), and Chamberlains Barn II, Bedfordshire (Hyslop, 1964), and both grave orientations were found in similar numbers at Great Chesterford, Apple Down and Berinsfield.

One of the most frequent interpretations made from grave orientation is that of religion, particularly Christian religion. It has often been assumed that Christian burials were interred $\mathrm{E} / \mathrm{W}$ and without gravegoods. However, this is not the case; the orientation of graves and the presence or absence of crosses (for example cruciform brooches) or the absence of other objects has 'no particular Christian significance' (Hyslop, 1964: 72; also see Geake, 1992). Moreover, graves oriented on an E/W axis are the most commonly found burials in both pagan and Christian cemeteries (Meaney and Chadwick Hawkes, 1970: 53; Faull, 1977). Other arguments include ethnicity (Faull, 1977) or notions of a 'good or bad direction' (Devlin, 2007b: 51), or have focused on the presence of earlier features around which graves were oriented. Some of the burials at Deal had their head oriented towards the middle of the ring ditch, and a single burial at Dover Buckland also had its head oriented towards the centre of a barrow (Penn and Brugmann, 2007: 13; Evison, 1987: 152; Lucy, 2000b: 130). Stephen Sherlock and Martin Welch (1992: 17) argued that the rows in which burials had been arranged to the east of the Norton cemetery were deliberately oriented towards the grave within an ancient burial mound, but unfortunately this was only evidenced by a single piece of Bronze-Age pottery. Certainly, the location of cemeteries adjacent to earlier features, including barrows, is well known (Williams, 1998), but, even with radial arrangement like at Driffield, East Yorkshire, there is little evidence to suggest that graves were actively oriented towards a single point.

If the orientation of a grave was not influenced by date of death and does not signify religious affiliations or ethnicity, it could perhaps be considered a site-specific decision. Berinsfield is a good example of this since we have already established that there were at least two burial plots, in the north and the south of the cemetery. These groups were 
$\theta$
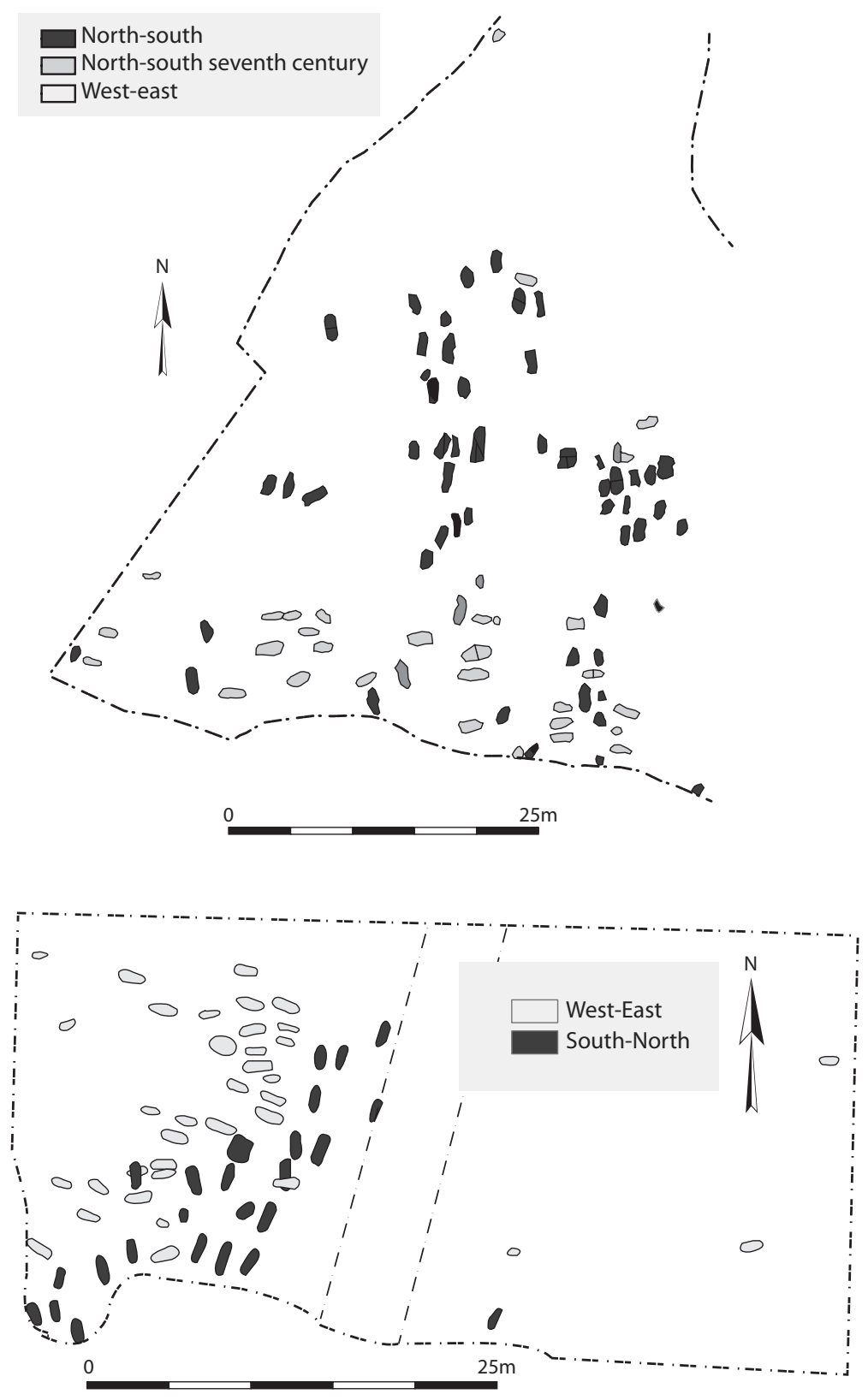

Figure 2.13 Cemeteries at Berinsfield, Oxfordshire (top), and Petersfinger, Wiltshire (bottom). Groups of graves here were spatially distinct and were also distinguished by their orientation. In both of these examples the difference in orientation is quite pronounced, with some graves broadly E/W and others N/S. 
further defined by the orientation of graves within them, and strikingly the northern group with a N/S orientation juxtaposed the southern group with an E/W orientation (Figure 2.13). Another notable characteristic of Berinsfield is that the seventh-century graves were intrusive; they were placed in an existing part of the cemetery and were deliberately positioned on the opposite axis to the earlier graves. Three such seventhcentury burials were found in the southern (E/W group). There was also one seventh-century burial in the northern group and, although this was $\mathrm{N} / \mathrm{S}$ like most of the surrounding burials, it deliberately cut into one of the few E/W inhumations, creating a similarly deliberate juxtaposition.

The early Anglo-Saxon cemetery at Petersfinger, Wiltshire, showed a similar pattern. This site was partially excavated in 1948-51 and seventy-one inhumations were discovered (Leeds and Short, 1953). Unlike Berinsfield the graves were not organised into spatially defined plots, but seem to have been separated into two groups using their orientation to make this distinction. All of the N/S burials were located on the south and east of the site and most of the E/W burials were to the north and west of these. Interestingly, in the middle of the site there were two later graves that evidently cut earlier burials, and both of these graves were positioned on a different orientation to the ones they cut, intentionally contrasting with the earlier individual burial and the associated burial tradition.

One of the most complex uses of juxtaposed burials to define groups of graves and individual graves was seen at Great Chesterford, which was excavated in 1953-5 and revealed 161 inhumations and 33 cremations, though unfortunately only part of the cemetery had survived (Evison, 1994). Based on a small number of Roman cremations, Evison proposed that there had been a series of large Roman barrows on which the cemetery was focused. She went so far as to suggest that individual nuclear family units were placing their dead within particular Roman barrows. This is not a pattern that has been seen elsewhere; however, the orientation of each burial, as at our three previous cemeteries, did correspond to separate spatial clusters of graves oriented on the same axis and contrasting with the adjacent group (Figure 2.14). At the south of the site there was a group of predominantly N/S oriented burials, and to the north-west of those was a small group of $\mathrm{E} / \mathrm{W}$ oriented burials, followed by a N/S oriented group with a large $\mathrm{E} / \mathrm{W}$ oriented group in the middle of the site. Five N/S burials may have been deliberately placed within this cluster, and this central area seems to be the most densely clustered part of the site. To the north of this there were a series of N/S oriented burials. At the very northern tip of the excavated area another group of $\mathrm{E} / \mathrm{W}$ burials was identified and, like the rest of these clusters, this group must extend into unexcavated areas. These groups of burials 


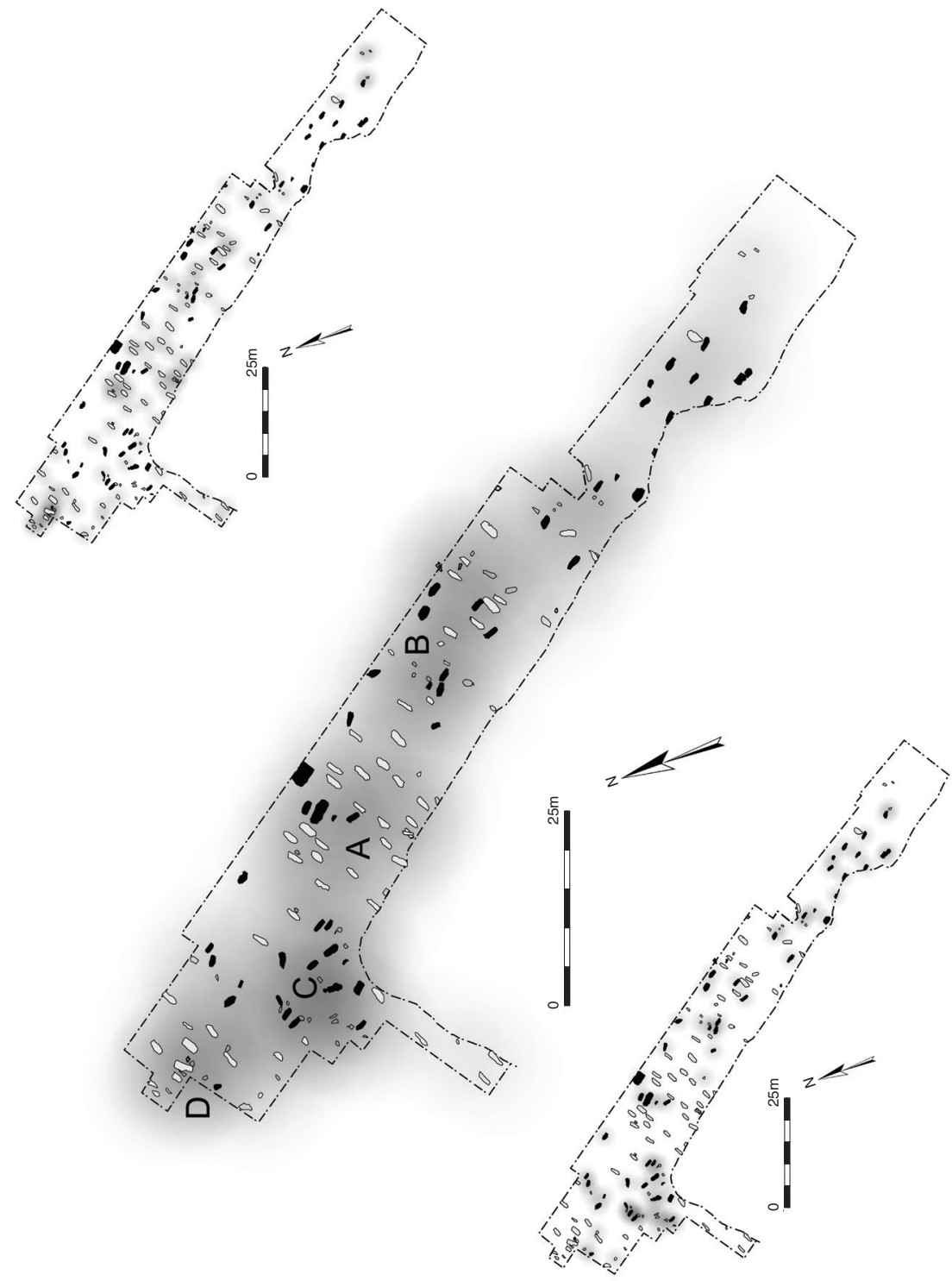

Figure 2.14 Great Chesterford, Essex, with the N/S-oriented graves shown in black. The middle illustration shows the cemetery with a heat map set at $10 \mathrm{~m}$ and illustrates the relative density of graves. The top illustration shows the E/Woriented graves with the heat map set at $3 \mathrm{~m}$. The bottom illustration shows the $\mathrm{N} / \mathrm{S}$ graves with the heat map again set at $3 \mathrm{~m}$. These plans show four deliberate clusters of graves (A-D), where D and C were defined by their orientation, $\mathrm{A}$ contained a core of N/S graves and B was a mixed-orientation plot. The southern part of the site contained dispersed graves. 
may not have been individual clusters, as they were at Berinsfield and Petersfinger, but were subgroups of graves within more complex groups. The N/S burials were distributed in smaller groups which defined the extent of the densely packed E/W oriented graves. These were just like the E/W burials at Apple Down because they enclosed a more densely packed central area (see Chapter 4).

The orientation of graves at these four sites appears to have been used to subdivide each cemetery into different groups. These were used to define clusters separated by a gap, or as a method employed to define discrete plots of burials. At Berinsfield and Petersfinger, later burials were juxtaposed on different orientations to distinguish them from earlier burials where they were either placed within a pre-existing plot or else truncated an earlier inhumation. This use of orientation to define a new phase in burial practice is also seen at other sites, for example Deal (Sayer, 2009) or Lechlade (see Chapter 6). Orientation was, therefore, a tool which could be used at multiple scales within a repertoire of cemetery semiotics to distinguish different groups of burials within the same phase or to differentiate later inhumations.

Not all sites employed grave orientation to such an overtly organisational degree: Spong Hill, Morning Thorpe, West Heslerton, Deal and Sewerby had only a small number of burials on a different axis, but at these sites this contrast was a powerful visual tool utilised to distinguish individual inhumations. Like body position, grave orientation seems to have been used to distinguish a particular individual, or small groups of individuals. This was also the case at Oakington, Cambridgeshire, where a pregnant woman was found buried $\mathrm{E} / \mathrm{W}$ in a cemetery of predominantly N/S graves (Sayer and Dickinson, 2013). Alternatively, when employed for a small number of burials, contrasting orientation could have been used to mark out special, prone or otherwise 'deviant' burials (Reynolds, 2009: 74). Given this variation, orientation was a cemetery-specific tool, and broader social concepts like religion, ethnicity or a 'good or bad' direction are too imprecise or grand to fit. Orientation was a multi-scale semiotic used within a community to separate individuals, for a variety of reasons, or groups of burials within a space; its effect was visually striking but it was not used consistently across all early Anglo-Saxon sites.

\section{Burial rites}

Two types of burial rite co-existed in the fifth and sixth centuries AD, inhumation and cremation. Previous scholars have suggested that cremation was the earlier of these two forms since it was the dominant burial rite on the Continent (Lucy, 2000b: 119-21). At Spong Hill, cremation started early in the fifth century (Hills and Lucy, 2013). 
However, the dates for cremation and inhumation burials are generally contemporaneous. Cremation seems to go out of fashion by the end of the sixth century, but its use spans the fourth to seventh centuries with some notable late examples in barrows at Asthall, Oxfordshire and Sutton Hoo, Suffolk (Dickinson and Speake, 1992; Carver, 2005: 105). The cremation rite differs from the inhumation rite in a number of ways, including the technology that was used - cremation requires a funerary pyre and several more stages in the funerary process: the act of cremation, collecting the remains and burying them in an urn. However, there also seem to be variations in the materiality of the cremated corpse; for example, cremated males were interred with weapons less than 1 per cent of the time as opposed to 47 per cent of the time in inhumation graves. It would seem that the decisions which motivated the selection of cremation or inhumation may have been more complicated than simply selecting a type of funeral and a type of burial (Härke, 1990: 25; Härke, 1989: 49; Williams, 2005).

\section{Cremation cemeteries}

Archaeologists have often thought of cremation and inhumation rites as separate and as a result have investigated either inhumation burials or cremations and only occasionally both; this is particularly well illustrated by Howard Williams:

Many communities in early Anglo-Saxon England had a choice between at least two contrasting mortuary technologies, cremation and inhumation ... It is also tempting to see the two rites as arbitrary distinctions: both rites were concerned with the visual display of the dead (in grave or pyre) and their subsequent interment albeit leaving very different archaeological traces. Alternatively, it is possible to regard the disposal methods in terms of binary opposites involving contrasting trajectories of the dead, perhaps linked to diametrically different 'meanings', attitudes towards social personal, and world views. (Williams, 2011: 241)

This wholly contrasting way of describing graves and particular burial rites has also been used to describe cemeteries. This convention probably stems from Audrey Meaney's Gazetteer of Early Anglo-Saxon Burial Sites which was used as source material for the Ordnance Survey's Map of Britain in the Dark Ages (Meaney, 1964: 15). Meaney assumed that the 'Angles cremated and Saxons and Jutes inhumed', and she divided these sites into cremation cemeteries, inhumation cemeteries or mixed-rite sites. However, at the time of the gazetteer's publication 
Illington, Norfolk, was the only cremation site to have seen detailed archaeological investigation.

Unfortunately, at the time of writing, Illington has still been only partially excavated and its assemblage currently consists of 212 urns and three inhumations, implying that there may be more of both types of burial (Wells, 1960: 29; Meaney, 1964: 15; Davison et al., 1993). Illington is a mixed-rite cemetery and on closer examination so are numerous others from Meaney's gazetteer. For example Ancaster, Lincolnshire, was classed as a cremation cemetery, yet Meaney noted that skeletons had also been found (Meaney, 1964: 151). Subsequent excavations have revealed inhumation graves elsewhere, including at Spong Hill in Norfolk, Snape in Suffolk, and Cleatham in Lincolnshire where about 95 per cent of the site has now been excavated, revealing 1,014 cremation burials and sixty-two inhumations (Hills et al., 1984; Filmer-Sankey and Pestell, 2001; Leahy, 1998). Baston, also in Lincolnshire, has been only partially excavated, revealing sixty cremations to the south, but there have been enough good-quality early Anglo-Saxon metal artefacts identified by the Portable Antiquities Scheme to suggest the presence of inhumations (Mayes and Dean, 1976; Williams, 2002a: 352).

In total Meaney listed seventy-six cremation cemeteries; however, of these thirty-two consisted of just one cremation and eighteen consisted of fewer than ten. Of the larger sites, seventeen were partially excavated in the nineteenth century or before; Kingston-on-Soar in Nottinghamshire, for example, contained over 200 urns but only sixteen were rescued (Meaney, 1964: 200). Newark, Nottinghamshire, was first identified in the 1740s and was explored a number of times in the nineteenth century, yet few remains now survive (Meaney, 1964). South Elkington, Lincolnshire, consisted of 250 urns but has not been entirely excavated (Bennet, 2009). Other large sites like Wold Newton, Thurmaston or Hall Hill, in Leicestershire and Lincolnshire, have had only limited excavation (Williams, 2002a: 353). Older investigations at Brettenham, Castle Acre and Drayton, all in Norfolk, were not fully explored by their nineteenth-century finders because their intent was on discovering urns (Williams, 2002a). Even well-known sites like Lackford, Suffolk, or Sancton, Yorkshire, remain only partially excavated (Lethbridge, 1947; Myres and Southern, 1973). This incompleteness of excavation is problematic; at Spong Hill, for example, all the inhumations were concentrated in just one area with significant clustering at $1 \mathrm{~m}$ - a phenomenon which may have been repeated elsewhere (Figure 2.15).

There seems to be a consistent association between cremation and inhumation graves, and even sites which we routinely consider inhumation cemeteries, such as Norton, Great Chesterford, Sutton Hoo, 


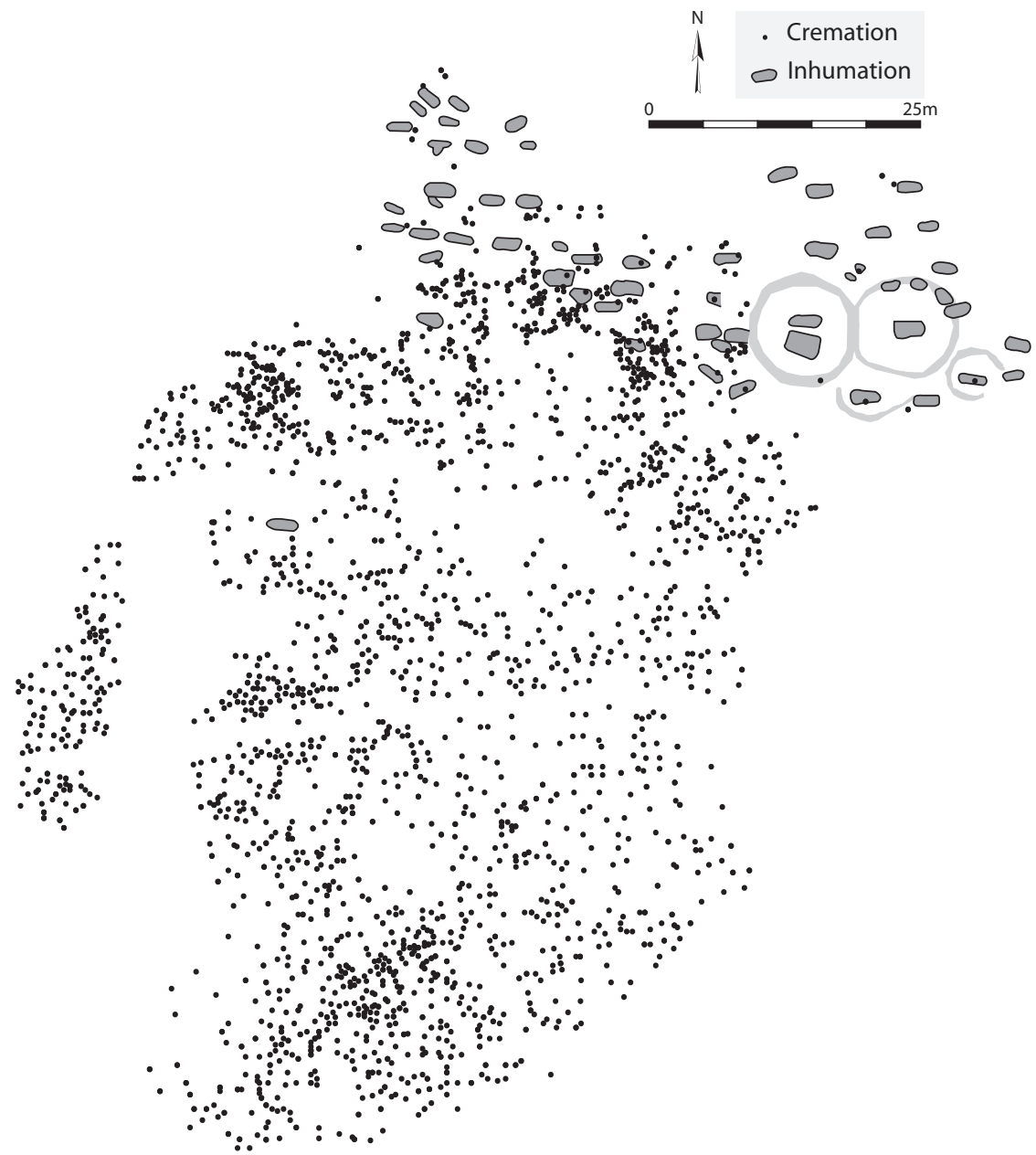

Figure 2.15 Spong Hill, Norfolk. The significant majority of inhumations were concentrated in the north of the site and the preponderance of cremations was found in the south, with some cremations and inhumations intermingled. This visually separated the two areas, since the south consisted of cremations and the north consisted of both cremations and inhumations, which were largely contemporary.

Blacknall Field or Berinsfield, often included a small number of cremations. Perhaps these different technologies were not considered to be wholly contrasting by their users. Rather, inhumation and cremation may have been at two ends of a range of a funerary syntax available for deployment at a cemetery or individual scale and to different degrees across Britain and between the fifth and seventh centuries AD. This view is shared by Penn and Brugmann, who looked in detail at four 
cemetery sites in East Anglia, where 'the differences between cremation and inhumation burial practice may not have been as fundamental as the archaeological evidence seem to suggest at first glance' (Penn and Brugmann, 2007: 96).

\section{Mixed-rite cemeteries}

Most, if not all, sites with cremations are mixed-rite cemeteries. They range from sites which contained large numbers of both ritual forms, such as Spong Hill, Caistor-by-Norwich, Andover or Apple Down, to sites which contained a small number of cremations, including Worthy Park, Hampshire, Norton and Berinsfield. This variation in the employment of cremation burial suggests that it was a multi-scale funerary technology used to distinguish either individuals within a predominantly inhumation site or specific groups of individuals within large mixed-rite cemeteries. Mads Ravn suggested that Spong Hill contained five or six burial plots consisting of cremations or inhumations (Ravn, 2003: 123). Visually, Spong Hill can be divided into two spatially distinct groups, the inhumations and cremations to the north and the majority of cremations to the south (Figure 2.15). Ravn also suggested that inhumation graves are evidence of an emerging elite group who used a separate burial form to distinguish themselves from the rest of society. This deliberate spatial and ritual differentiation is very similar from the burial plots visible at Wakerley and Berinsfield, or the different grave orientations seen at Apple Down and Petersfinger. The community using Spong Hill cemetery engaged separate spaces and juxtaposed different burial rites as a primary organising feature. This is an organisational characteristic which can also be seen at Alwalton, Cambridgeshire, where twenty-eight cremations were found in the western half of the excavated area and thirty-four inhumations in the eastern half (Figure 2.16; Gibson, 2007).

The division of mixed-rite sites into practice-related zones may have distinguished between two groups using the same site (Williams, 2002b), and patterns like this can be found at Andover (Cook and Dacre, 1985), where cremations were mostly located on the western side of the site with a small cluster of eight or nine inhumations in the middle of this area (Figure 2.17). These burials, both inhumation and cremation, were spatially distinct; by putting the different rituals in different physical spaces the funerary architects reinforced the semiotic division between two distinct groups within the community. Interestingly, Caistor-by-Norwich (Myres and Green, 1975) is similar to both Spong Hill and Andover, which seem to have been organised around a series of spatially distinct areas where the centrally located clusters have the highest concentration of cremations and also, notably, the largest number of inhumations. 


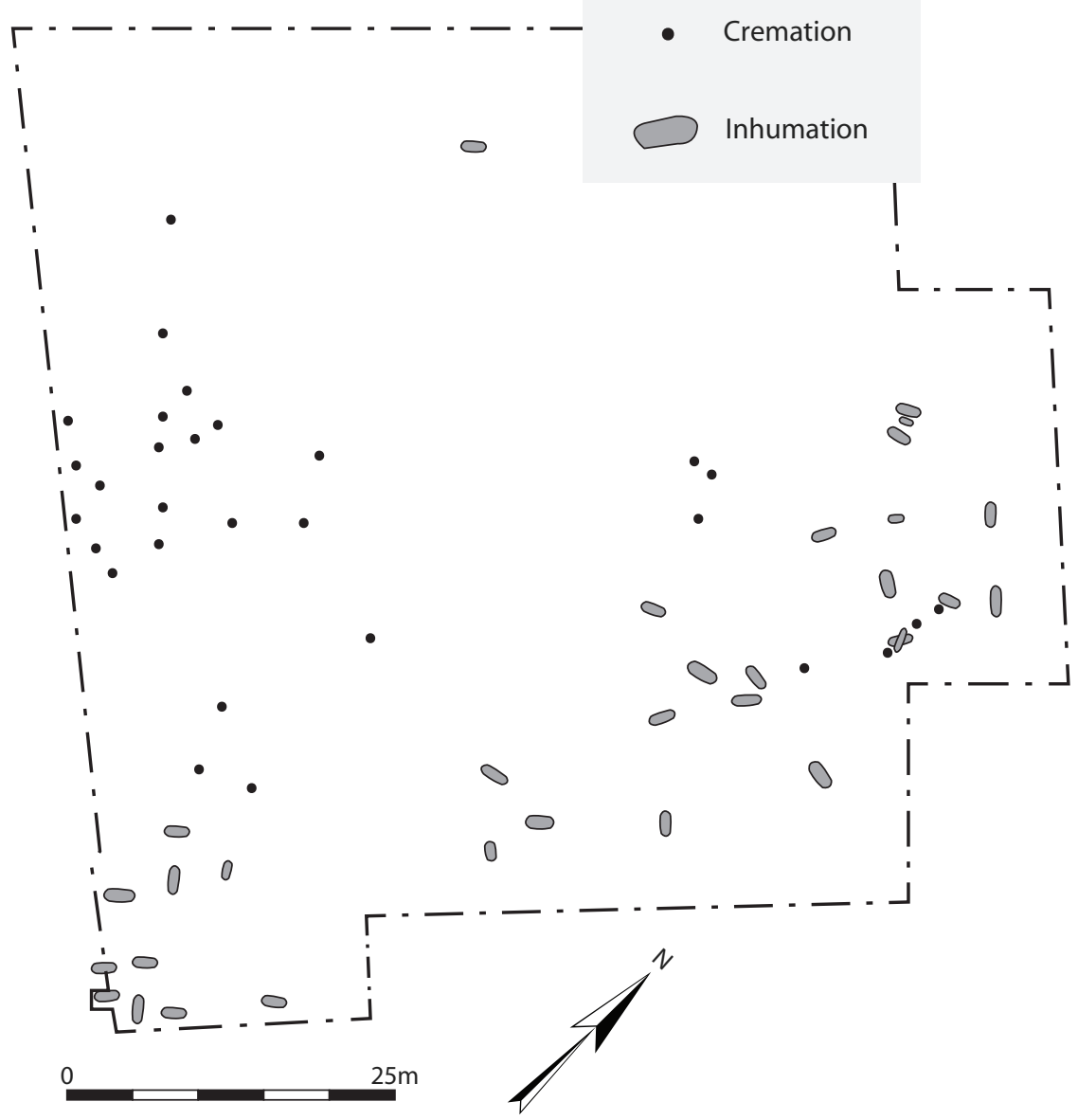

Figure 2.16 Alwalton, Cambridgeshire, was spatially separated into two groups: a cremation group and an inhumation group, which included just a few cremation graves.

Like Andover and Spong Hill, Caistor-by-Norwich seems to have been organised into distinct spatial areas. The clustering of graves was significant at $1 \mathrm{~m}$ separation, placing emphasis on high density of burial. Unlike Spong Hill, the plots at Andover and Caistor-by-Norwich combined inhumation and cremation burials, but (like Spong Hill) those at Caistor-by-Norwich were very dense, with many cremations clustering at $1 \mathrm{~m}$ and inhumations at $3 \mathrm{~m}$. Cremation graves require less space than inhumation graves and so this high density suggests that Caistorby-Norwich began as a closely packed cremation cemetery, like Spong Hill, and the inhumations were added later (see Chapter 3). The two groups who buried their dead in the middle of the cemetery used the 


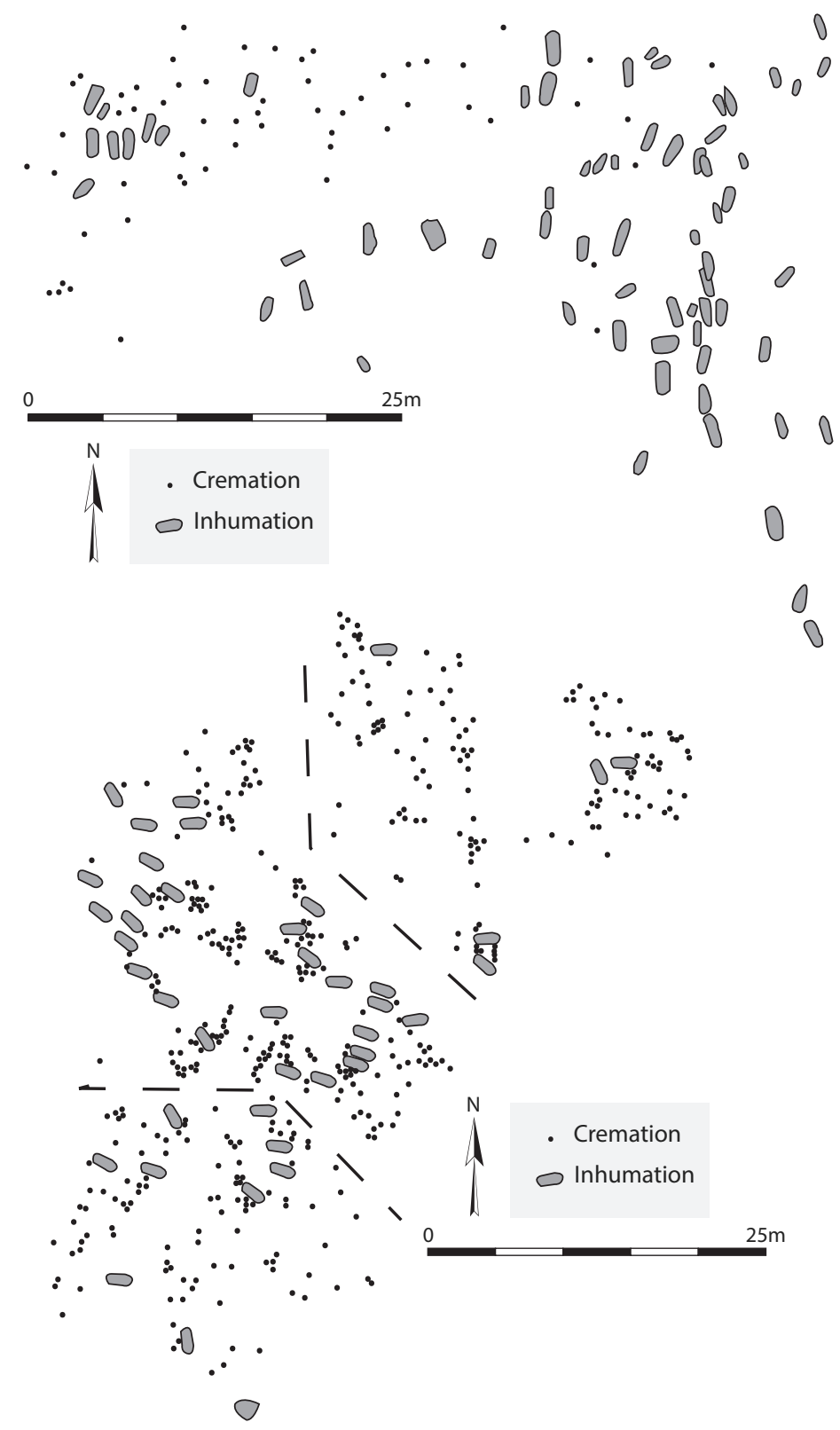

Figure 2.17 Andover, Hampshire (top), Caistor-by-Norwich, Norfolk (bottom). At Andover the majority of cremations were to the west of the site with a small cluster of nine inhumations in the middle. The east of the site included just a few cremations and the majority of graves were inhumations. The Caistor-by-Norwich graves clustered at $1 \mathrm{~m}$, with evident groupings at $3 \mathrm{~m}$; the central plots $\mathrm{A}, \mathrm{B}, \mathrm{C}$ and $\mathrm{D}$ were the densest groups of graves and contained the most inhumations. 
most inhumations, and these may have been the longest-lived groups in the community. These spatial areas were large and the decision to cremate or inhume an individual may have taken place within particular social groups rather than between them, as at Spong Hill or Andover. Therefore, in these two examples cremation was a strategy employed to distinguish separate internal groups or identities within a particular extended social group.

As Howard Williams (2011) argued, cremation was a funerary technology that existed to contrast with inhumation but, just like grave orientation, burial plots and the density of graves, it was part of a semiotic toolkit used within the repertoire of cemetery-specific syntax. Cremation seems to have operated at different scales within different communities: at Spong Hill, cremation was used in combination with burial proximity to define the cemetery space; at Andover, cremation and clusters of inhumations were used in conjunction to mark out different groups; and, at both Andover and Caistor-by-Norwich, individual plots consisted of cremations and inhumations. By contrast, at Berinsfield and Worthy Park, cremation was used for only a few funerals, signalling their difference from the rest of the cemetery population.

\section{Material culture}

The types and distributions of material culture within Anglo-Saxon cemeteries have been discussed in several ways. The first of these is focused on the use of particular types of objects as identifiers of ethnicity, where certain brooch types appear to have been distributed across particular regions of the country (Leeds, 1913; 1936). Cruciform brooches are absent from many of the southern counties, where great squareheaded brooches are more common. Girdle hangers, by contrast, seem to be more common in Kent and East Anglia, wrist clasps are found in Cambridgeshire and the Midlands, while cognate brooches are concentrated in Rutland and the Midlands. Applied brooches are found in the South-East of England, button brooches are concentrated in Kent and the Thames Valley and many disc brooch types are found in the Thames Valley region as well as the Midlands and East Anglia (Lucy, 2000b: 134-5). Distributions like these have led many authors to conclude that there were regional or group costumes (Hines, 1994: 52-3), which may have been used as indicators of the evolving expression of regional ethnicity - Saxons, Angles or Jutes for example (Böhme, 1974; Leeds, 1913; 1936; 1945; Chadwick Hawkes, 1969). This association of specific graves, and even objects, with regional variance resulted in them being assigned ethnicity (Lucy, 2000b: 169). However, Lucy (2000b: 174) also proposed an alternative: if these distributions did manifest 
ethnicities, they were complex mixtures of political and ethnic affiliations. Susanne Hakenbeck, investigating Bavarian cemeteries that were contemporary, identified the distribution of brooch types and weapon burials within four sites as a plurality of expression. Objects, grave locations and funerary rites were all locked up in a multi-layered set of social circumstances that may have included ethnicity, kinship or warrior status (Hakenbeck, 2007a; 2007b; 2011).

In the past, archaeologists have tried to use the distributions of brooches to understand specific and individual ethnic affiliations within cemetery sites (Koch, 1998; Hakenbeck, 2007b; 2011; Lucy, 2005). One difficulty with this approach is its simplicity: male gravegoods have been interpreted as indicators of status, and female gravegoods as indicators of ethnicity (Härke, 1990; 2000; Stoodley, 1999; Lucy, 2000 b). However, brooches, particularly elaborate brooches, like other art forms are wrapped in multiple meanings associated with a plurality of underlying social factors like ethnicity, family identity, status indicator and even personal choice.

Cemetery sites are not just places where people buried their dead; they are also places where people remembered them. As a result, material culture may reflect a remembered continuity - a punctuated, ad hoc similarity - where one grave is similar to, but not identical with, an adjacent early burial because the funeral party remembered some of the aspects of that earlier event but reinterpreted the rite, influenced by their own relationships to the recently dead (Sayer, 2010). Williams (2006: 36-78) investigated combinations of material culture and gender/age patterns in Berinsfield, Deal and Harford Farm, Norfolk, to approach the question of cemetery structure, not from an organisational perspective, but from the question of burial ritual and memory. He used the physical proximity and similarity of grave assemblages to discuss the repetition of ritual and therefore the active memory of the participants in the funerary rites. Equally, Zoe Devlin describes memory as an active, not passive, process where the act recreates a past, and objects, rituals or procedures can be forgotten and reinvented during that process (Devlin, 2007a; 2007b). Subsequently, objects were not simply transmitted and interred, but were imbued with social and personal meanings which were then considered, described and recreated in the placement of objects in later graves.

Williams (2006: 36-78) focused on brooches and weapons to understand his cemetery sites; whereas previously Pader (1982) considered that it was the less significant objects, such as tweezers and pins, which might be indicators of divisions in cemeteries. This is an interesting idea as ethnicity, family or social identity - expressed through the material culture within relationships - can be reinterpreted or forgotten when 
these identities are renegotiated by subsequent generations. What was a round disc brooch when put in a grave may have become subsequently a small square one when remembered through an oral tradition. The material associated with activities, for example the communal preparation of a corpse, may survive in a funeral rite as part of a localised but evolving ritual process.

As detailed above, Wakerley was divided into three contemporary groups of graves or plots; what is striking about this site is the distribution pattern of common dress objects, particularly buckles and pins (Figure 2.18). Two pins were found on the west side of the cemetery, only one pin on the east, yet in the middle there were five. However, even more notable is that six of the nine type-II buckles, those with a backplate, were concentrated in one of the three grave plots, the eastern group of burials (group C in Figure 2.3). This pattern is interesting when considered next to the distribution of brooches. Four of the six cruciform brooches were found in the eastern of the cemetery, whereas the less elaborate small-long brooches were found across the site. There were only two great square-headed brooches from this site, one on the east and one on the west, and there was just one imported small squareheaded brooch from the west. This distribution of artefacts seems to confirm the spatial division of the cemetery into three plots with a western A, central B and eastern C group of burials. The distribution of objects suggests that the social groups who interred their dead in each of these areas treated their dead slightly differently: the eastern group in plot A dressed their dead in more elaborate costume, with more visually elaborate objects, illustrated by the presence of more ornamented brooches and more belt buckles with backplates; the central and western burial plots had a similar but less elaborate funerary costume.

This phenomenon is conceivably the result of several underlying social situations. The site seems to have contained evidence for a single style of female dress, which included annular brooches (not illustrated), small-long brooches and belt buckles. This tradition is common to the community at large, with a few burials in the eastern area showing a similar second tradition superimposed on this first one, and including cruciform and more elaborate brooches as well as more visually impressive buckles. Given that funerals are enacted by the living in the community, it is important to consider who was conducting and participating in these events. For the first, simpler, funeral tradition, the ritual is comparable across the site, so it was drawing on a collective communal memory, and it was this community who must have been the main audience for these funerals, as it was they who would have understood the symbols and associations made in each burial event. For the second, more selective, style the rite had been developed for a second group who 

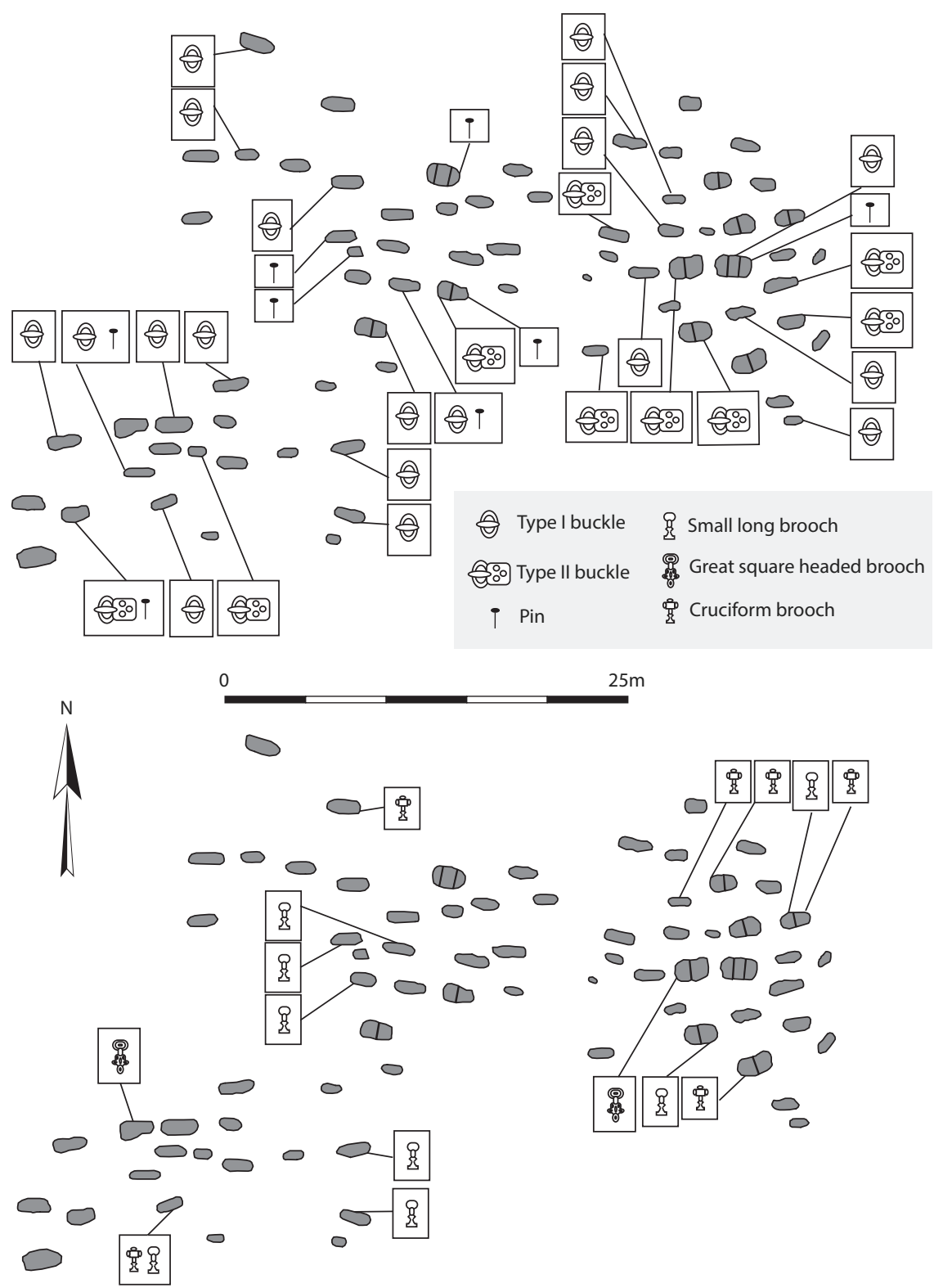

Figure 2.18 Buckles and pins at Wakerley, Northamptonshire (top). Notice that the type-II belt buckles were more common in the easternmost plot, and pins were commoner in the two western plots. Equally, the more elaborate brooches (bottom) were found to the east, with simple small-long brooches being most common in the two western plots. 
may not have understood the particulars of the community tradition, but who would have understood the broader cultural references that were visually employed in this rite. This second dress style was more elaborate, suggesting these individuals were being identified as part of a wealthier group. As a result, we might conclude that the audience for the funeral probably included people from outside the immediate community who would have interpreted the social value of imported and decorative items within a wider societal context. Each individual or group participating in a particular funeral would have recognised certain elements of this rite at a personal, community and cultural level, both as an event and rooted within the plurality of meaning embedded within the objects and rites employed.

The Anglo-Saxon cemetery at Deal was largely sixth-century in date, but some of the graves dated to the early seventh century (Parfitt and Brugmann, 1997: 1-6). Like many Kentish cemeteries it was richly furnished, and most graves contained objects; however, as with Wakerley, there was a pattern to the distribution of some of these objects (Figure 2.19). For example, in the cluster of graves at the north

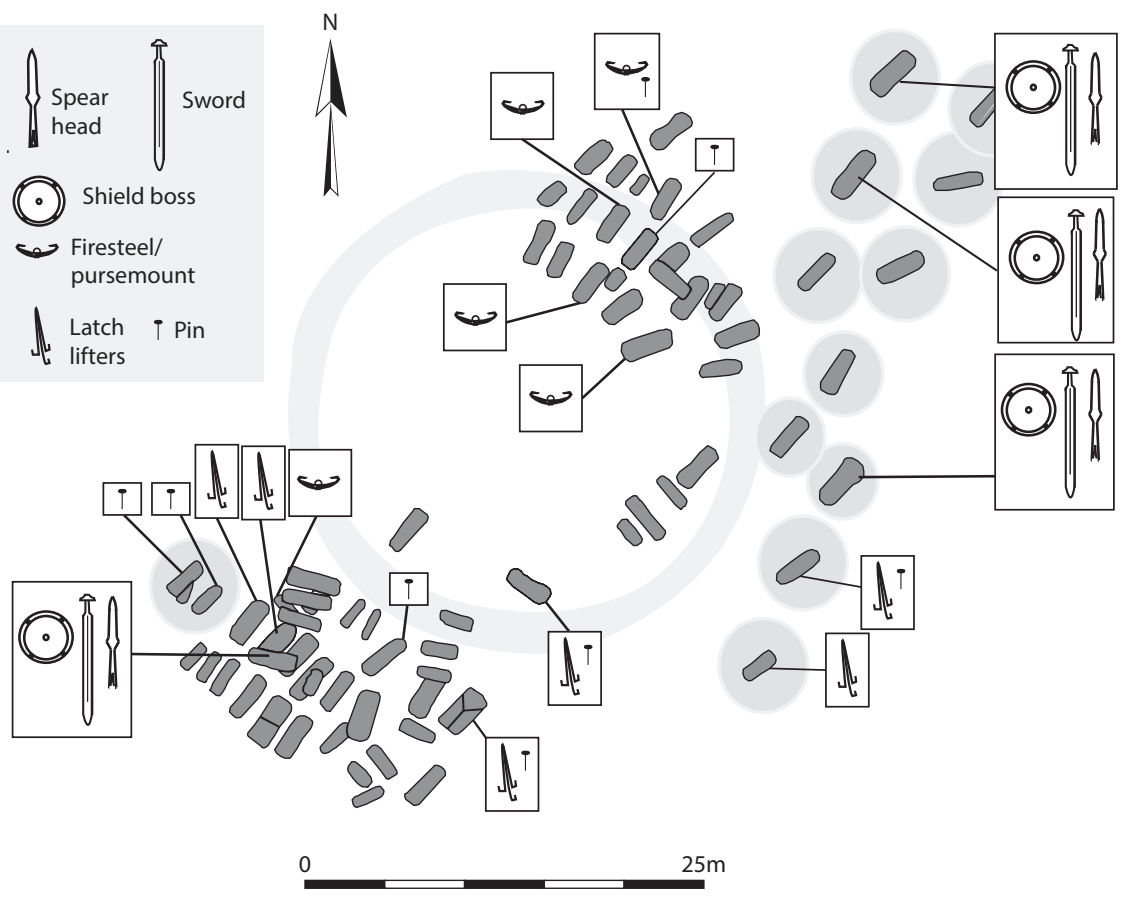

Figure 2.19 Patterns in the distribution of objects at Deal in Kent. Firesteels were more common north of the barrow, with pins and girdle-hangers to the south.

Weapon burials with swords were more common in the line of graves to the east. 
of the site there were four firesteels/pursemounts; whereas only a single one was found in the cluster in the south of the site. Similarly, six of the eight pins were found in graves in the southern part of the site, as were all six of the latch lifters. Many of the male graves at Deal contained weapons but, of those which included swords, three were in a group of burials in the eastern part, and only one was in the southern section.

The brooches found at Deal consisted of Kentish garnet discs, radial-headed, bird- and square-headed brooches. These objects were distributed around the site and their selection for burial probably depended on the individual choice of either the deceased or of the people who dressed their corpse. However, in the sixth-century burials it was the less conspicuous, functional objects which formed part of different localised funerary traditions. Presumably the use of these objects in graves was the result of two separate intra-community groups who passed on their own, independent traditions for dressing a corpse for burial. The male weapon burials were all late-sixth- or early seventh-century and were part of a second phase in the use of this site. However, the use of swords signalled a discontinuity from the older tradition and contributed to the creation of a new, localised male funerary rite, graves under mounds concentrated in a new, less dense and dispersed area of the cemetery (Sayer, 2010).

These examples demonstrate quite different distributions of material culture within each cemetery. In two cases, Wakerley and Deal, the distributions were evident in household objects, and in the selection of particular types of object. At Apple Down and Morning Thorpe (see Chapter 6), the difference manifested in the ritual, which dictated the type of burial assemblages to include within a grave, as much as in the material culture. 'Less significant' objects like pins, buckles and firesteels were part of these assemblages, but objects like brooches and weapons also displayed rather subtle patterns of deposit in early Anglo-Saxon cemeteries. Williams (2006: 52) investigated the early Anglo-Saxon cemetery at Berinsfield and suggested that great care had been taken in the selection and layout of gravegoods, particularly brooches. He discussed the attention to detail visible in graves 104 and 91, which were adjacent, oriented on the same axis, contained pots, small-long brooches and beads, and displayed similar body positions. However, there were also subtle differences between them: for instance, grave 104 did not have a copper-alloy pin, but did have twice the number of beads, and had charred logs along the graveside. This attention to detail is a universal part of the early Anglo-Saxon burial tradition, and it is interesting that the burials from Wakerley and Deal showed elements of continuity, indicating a desire to dress a corpse in similar ways among spatially similar burials. These details were learned, passed down and repeated for a number of burials within a particular social group. Identical adjacent graves are rare, so deliberate 
repetition was not the goal. However, elements of commonality ran through furnished burials in particular areas of each cemetery, suggesting uniformity of practice and detail with separate localised traditions that highlighted the individual.

How a corpse was dressed may have depended on the deceased, how old they were, and their gender (Stoodley, 2011), but it may also have depended on who was dressing that corpse and from whom they learned the techniques. Where bodies were laid out in graves fully dressed, surviving evidence such as brooches and pins can be used to reconstruct how women wore garments (Owen-Crocker, 1986; Rogers, 2007). Even burials found without dress items were probably clothed or wrapped. Burials may have been dressed in a specific way; evidence of veils, blankets, pillows or bags may have concealed or hidden objects, faces or other physical characteristics (Williams, 2006: 52). Knowing what was buried with an individual must have depended entirely on a person's level of participation in the funerary ritual. If a person cleaned, dressed or prepared a body and then laid it out in the grave, they would possess an intimate knowledge of the burial; whereas, if they only attended a funeral at the open graveside, they would have a more limited knowledge of the grave's secrets. Williams also suggested there were several phases to a funeral: preparing, laying out - in the ground or at a hall and burial (Williams, 2006). The level of involvement a person or group had in a burial may have depended entirely on how they were connected to that person. Indeed, the distribution of objects at Wakerley, Deal, Morning Thorpe and Apple Down demonstrates that there were two or three different ways that bodies were prepared at each site. ${ }^{4}$ These methods were transmitted among the people who used particular parts of the cemetery to locate their dead.

\section{Compound cemeteries}

Not all cemeteries used just one method to visually distinguish their dead. Large cemeteries like Lechlade, Spong Hill, Apple Down, Springfield Lyons and Wasperton used complex combinations of cremations, ancient features and clusters, plots and densities of burial to structure their graves and highlight difference. Each of these burial strategies was visually evidenced within the cemetery space and provided a set of structuring principles. These devices created divisions within the cemetery space and these were powerful ways to structure the experience, providing an aide-memoire for the narratives used in funeral display and local storytelling.

The early Anglo-Saxon cemetery at Apple Down, West Sussex, was discovered in 1981 and excavated between 1982 and 1987. The 
site contained 121 inhumation burials and sixty-four cremations and, although it was in use between the late-fifth and early seventh centuries, the majority of the burials dated to the sixth century. The excavators, Alec Down and Martin Welch (1990: 9), suggested that the cemetery was arranged around a core of early burials which dated to an initial phase in the late-fifth and early sixth centuries. However, this nucleus of inhumation was predominantly sixth-century in date, like the rest of the cemetery, so cannot have been an earlier arrangement.

As we saw in Chapter 1, Apple Down was striking in its organisation and consisted of one large central mixed-rite cluster with a series of satellite graves. As a whole, the graves clustered at around $2.5 \mathrm{~m}$, but no patterning was evident when they were plotted as a kernel density map. This suggests a more subtle and internal organisation. This cemetery's major subdivision emphasised the differences between the E/W oriented inhumation graves, the N/S oriented inhumation graves and the cremations. Within the central area these burials were deliberately juxtaposed, by placement on different axes or using different rituals (Figure 2.20). Within the central mixed-rite group, cremations were clustered at $6 \mathrm{~m}$ and the $\mathrm{E} / \mathrm{W}$ graves at $5 \mathrm{~m}$, but the N/S graves were not deliberately clustered at all. This created a core of E/W oriented burials, two groups of cremations on both sides, and the N/S oriented group around the edges of the cemetery. Importantly, the N/S oriented graves did not cluster at all and so, although they were deliberately distinct from the N/S graves and the cremations, there was no attempt to structure their placement.

Apple Down is not the only cemetery which used multiple methods to divide its burial population. Wasperton, in Warwickshire, was excavated between 1980 and 1985, and 215 inhumation burials and twenty-six cremations were uncovered that used Roman, British and Anglo-Saxon burial rites (Carver et al., 2009). This early Anglo-Saxon cemetery was located mainly within a rectangular Romano-British field enclosure, which had been reused to create internal cemetery boundaries (Figure 2.21). The burials can be subdivided into two spatial groups separated by the surviving ditches, and the bulk of the cemetery was found within the larger quadrilateral enclosure, where graves concentrated with significant clustering at $3 \mathrm{~m}$. This clustering divided these burials into four groups, the central one of which included twenty-two of the twenty-six cremations and the highest density of inhumation graves. Two similar clusters of inhumation graves were found to the south and east of the central group and a fourth more loosely clustered group of burials was found to the east, mostly within the second enclosure. If treated independently this fourth group was homogeneous and showed no internal clustering. Outside the field enclosure only inhumations were found; these graves were deliberately more spread out and formed 


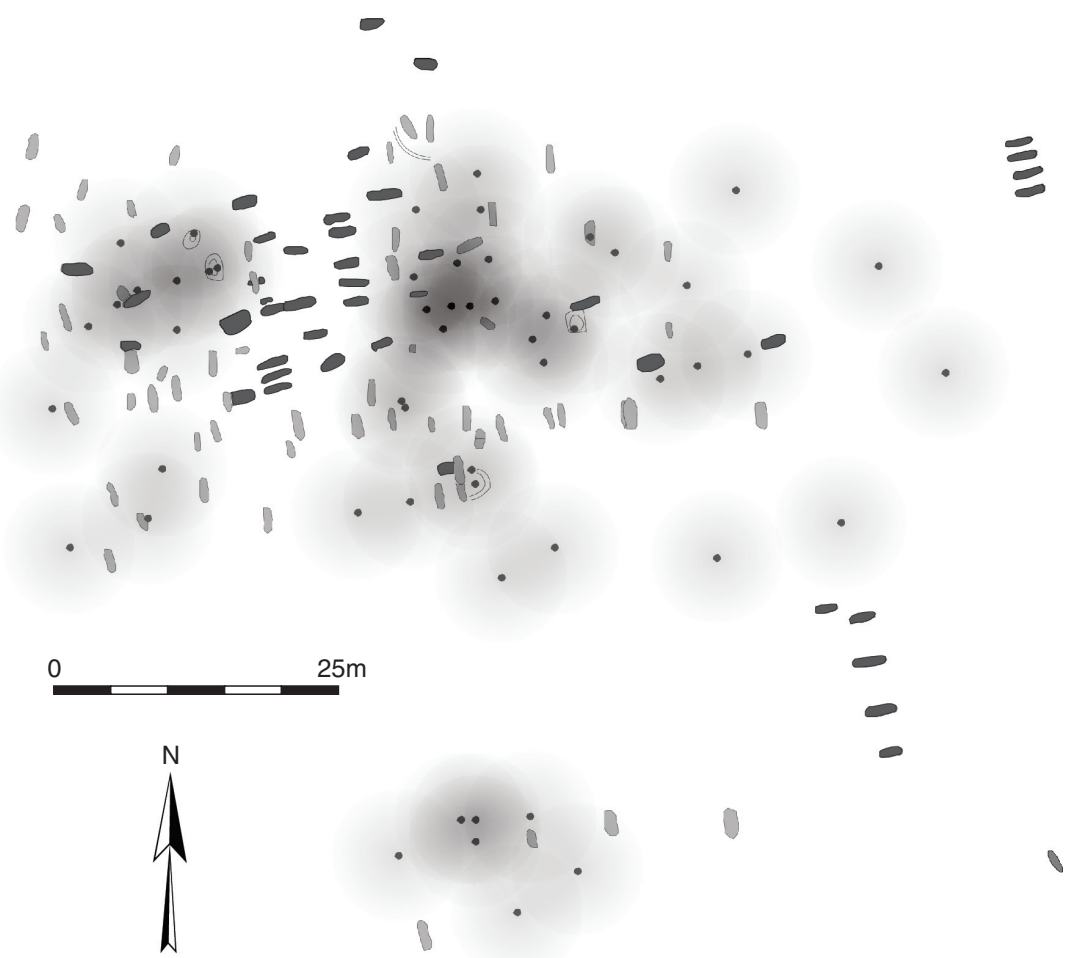

Figure 2.20 Apple Down, West Sussex, was a compound cemetery and used a mixture of spatial tools. The inhumations were distinguished by orientation with E/W and N/S graves; cremations were separated into two groups, clustering at $6 \mathrm{~m}$ on either side of the $\mathrm{E} / \mathrm{W}$ inhumation graves.

three small groups of burials clustering at $5 \mathrm{~m}$. The Wasperton cemetery employed a combination of plots, grave density and reused features to provide it with internal structure.

Springfield Lyons, Essex, used a different system and combined grave ritual, ancient features and spatial proximity. Like Apple Down and Wasperton, the cemetery was large, with over 250 individual burials 


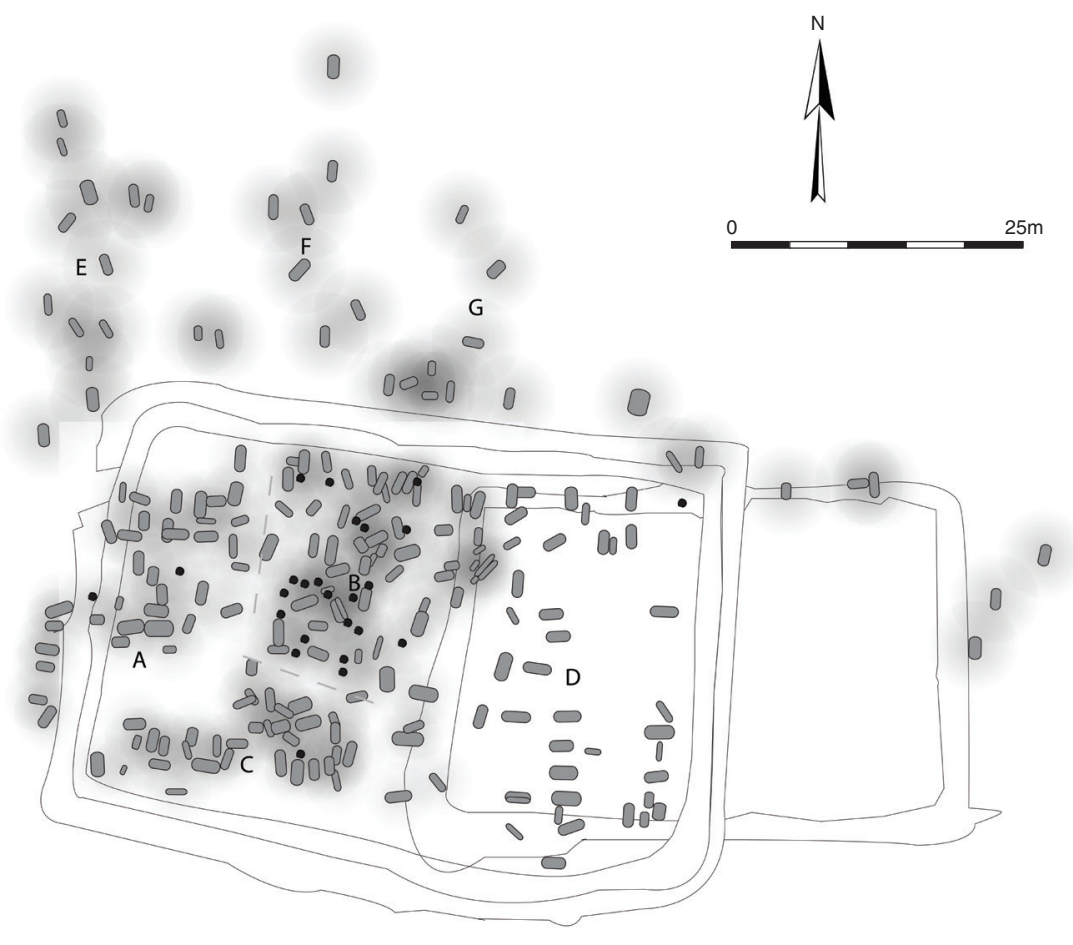

\section{$\infty 0$}

Figure 2.21 Wasperton, Wiltshire, was organised around a series of earlier ditches. Enclosed within the large sub-rectangular ditch were plots A, B and C, which were clustered at $3 \mathrm{~m}$. Plot $\mathrm{B}$ had the greatest density and the most cremation graves, and Plot A exctended beyond the enclosure ditch. Within the ditch complex, but separated by a smaller ditch from plots A, B and C, was group D; these graves were almost all placed apart, in deliberate juxtaposition to the clustered plots. Outside the sub-rectangular enclosure, groups E, F and G included less densely spaced graves clustered at $4 \mathrm{~m}$. There were a number of lone burials or small satellite groups around the edges of the cemetery.

(Tyler and Major, 2005). The graves statistically clustered at $2.5 \mathrm{~m}$ and, as at Apple Down and Andover, the cremations and inhumations were in different areas (Figure 2.22). In this case the clustered inhumations were to the south-west of a large Bronze-Age enclosure, with some burials placed within and on either side of the ditch. These were enveloped by the cremation burials on the south-eastern and south-western edges, and a small cluster of cremations were identified to the north-west of the enclosure. Unlike Caistor-by-Norwich and Spong Hill, the cremations 


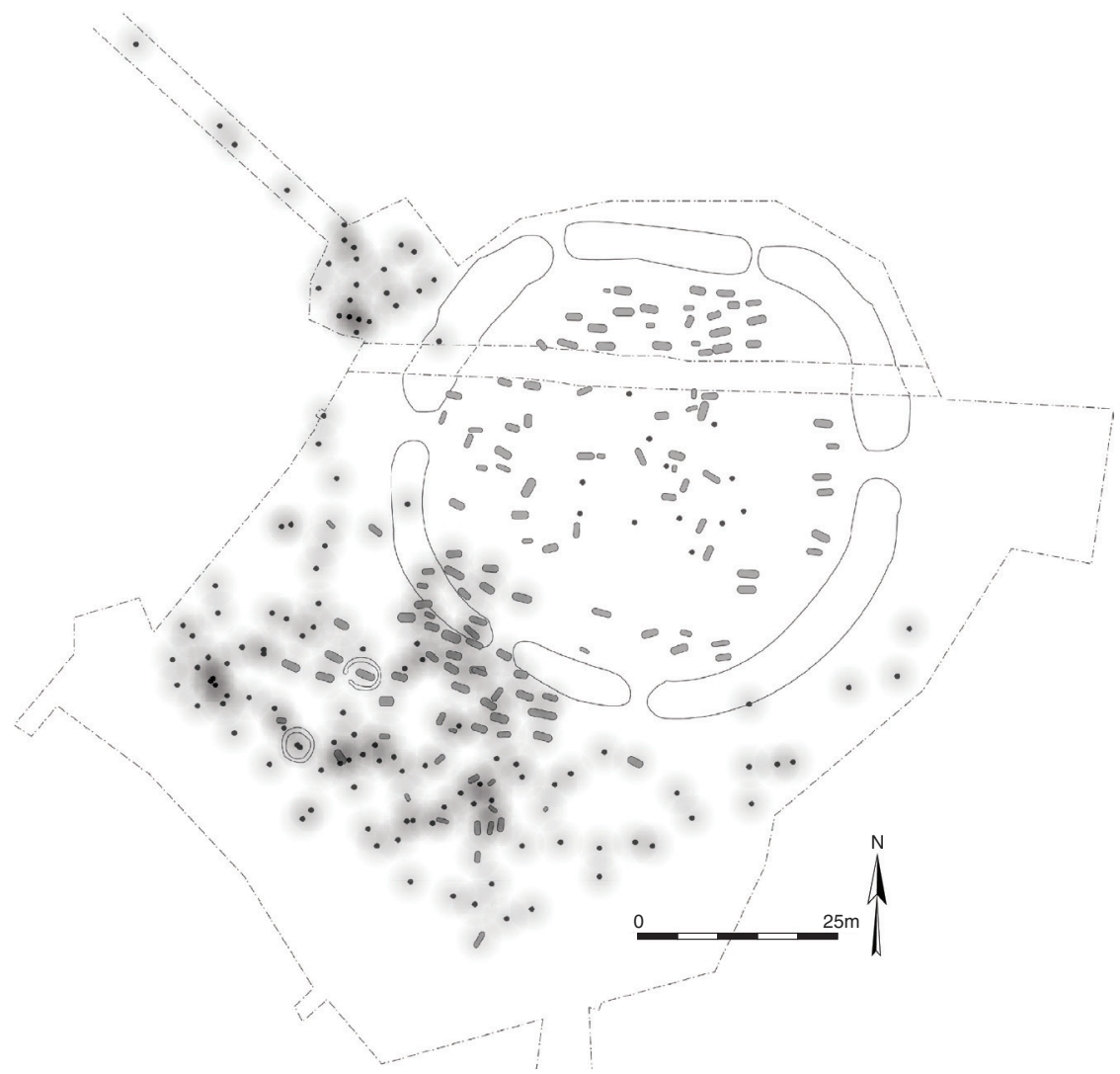

Figure 2.22 Springfield Lyons, Essex, combined grave ritual, ancient features and spatial proximity. The site was arranged around an earlier ring-ditch feature. Outside this, and overlapping the south-western portion of the ditch, was a tight group of graves that clustered at $2.5 \mathrm{~m}$. Around this was a dispersed group of cremations, and within the ring ditch was a more dispersed group of inhumation burials.

were spaced out which may indicate that they were contemporary with the inhumations, the large graves establishing the relative density of burial. In this case, the spatial location and burial rite provided structure for the syntax of the cemetery space. Importantly, however, there was a second group of inhumations within the reused enclosure, and these were homogeneous and more spaced out than the cemetery's main cluster of inhumations. Springfield Lyons was not organised into obvious spatial plots, although other tools from the mortuary portfolio had been used to structure the site, combining different rituals, densities of burial and ancient monuments to create a narrative syntax which separated groups of graves. 
Early Anglo-Saxon cemeteries were complex places without a single design. They were evolving mortuary landscapes created by a multitude of 'architects' for a variety of audiences. For archaeological investigation, understanding the space within the cemetery is as important as the contents of the graves. While simple sites might be divided into identifiable plots with groups of graves separated by a gap, almost sub-cemeteries within the larger site, the more complex sites were subdivided on a basis of different knowledge or experience. The emphasis may have been on grave density, orientation or clustering around a significant ancestor, and so these cemeteries contained a range of different funerary rituals. Grave plots, grave orientation, density of burial or clustering groups of graves provided visual differentiation, changing the texture of burial areas within a site. Large cemeteries were more likely to be complex, with more variation in the interpretation of mortuary practice, and they combined many different ideas which contributed to the whole.

\section{The structural syntax of early Anglo-Saxon cemeteries}

At first glance each early Anglo-Saxon cemetery appears different. However, there were a number of underlying, but comparable, narratives that defined their organisation. The communities that interred their dead in these cemeteries drew from a repertoire of mortuary syntaxes and applied them at a cemetery scale to subdivide the site; in doing so they created divisions within the composition which structured shared semiotic knowledge. The application of these practices seems to have varied from cemetery to cemetery, depending on which other technologies had been adopted for previous graves and how they had already expressed existing aspects of group identity. In the sixth century, the utilisation of cemetery space resulted from an aggregate of multiple perspectives and so the syntax used to express meaning could change over time. But, inspired by Merovingian practice, the North-East of England and Kent in particular witnessed a new phase, a later sixth- and seventh-century arrangement, where rows of graves gave an impression of order - for example, the square-shaped layout of the Street House cemetery. In addition, both phases cemetery activity were influenced by existing topographic elements like barrows, or earlier ditches. The location of a cemetery may have been chosen because these mounds and ditches presented attractive ways to shape and order the mortuary space and subsequently influenced how the communities commemorated themselves. Nevertheless, pre-existing semiotics were no longer fit for purpose and did not adequately express the shape that society had taken. Similar methods were used to express a new narrative; the rows, 
squares and dispersed cemeteries of the seventh century were akin to Merovingian sites, and perhaps the members of an emerging familial elite were using and adopting new styles of commemoration to fit their purpose.

Brian Hope-Taylor (1977: 262) and Heinrich Härke (1992: 169) described cemeteries as either monocentric or polycentric, based on the clustering of graves. This is a useful starting position, but only the smallest sites included just one method of organisation. Even the small final-phase cemeteries like Dunstable, Garton Slack II, Bargates or Caistor St Edmund consisted of several discrete groups of burials that could be separated by up to $150 \mathrm{~m}$. Moreover, visible burial semiotics were employed by the cemetery architects to divide a site into different groups, either by means of statistically observable grave clusters or densities used to define specific groups of graves, as at Berinsfield, Wakerley or Norton, or by creating a visible contrast by orienting graves uniformly, as at Berinsfield, Petersfinger, Apple Down and Great Chesterford. Nonetheless, orientation and grave plots were just two methods and the very ritual itself - cremation or inhumation - was also used to shape burial space at Springfield Lyons, Apple Down and Andover. Most early Anglo-Saxon sites were either inhumation cemeteries or mixed-rite cemeteries, and the latter used a combination of cremation and orientation or grave plots to subdivide funeral space. This practice can be seen at Spong Hill and Alwalton, where cremations or inhumations were located in particular zones of the cemetery, or at Caistor-by-Norwich, where cremation was employed to subdivide spatially distinct burial plots, probably by chronology. Cremation was used at multiple scales, and the small number of urn burials at Berinsfield or Worthy Park may have been used to distinguish individuals as opposed to groups.

Early Anglo-Saxon cemeteries were both complex and culturally specific, at both society-wide and local levels. They carried multiple messages because they were constructed by many architects over extended periods of time. They contained interpretations and reinterpretations, paradoxes and similarities, and they were designed as devices to be understood by people situated within an early medieval attitude. Individual sites contained continuities, and different funerary parties shared semiotic knowledge of the cemeteries, but they interpreted them according to their own rules using spatial patterning, grave orientation or topography. For the most part cemeteries were neither homogeneous nor random collections of unconnected burials (contra Barber, 2011: 6). Early Anglo-Saxon cemeteries were the products of social agents operating at multiple scales and within an existing and predefined space. Cemetery aesthetic was a mnemonic device used locally to communicate 
at a cultural level; it provided the physical space to support narrative discourse and provides a unique resource for archaeological investigation. But these structures were not just used to divide up contemporary space; as we saw at Deal, cemeteries were a palimpsest of overwriting, where each generation reinterpreted the space for their own ends. Gravegoods, cemetery space and burial ritual were a physical manifestation, an overt expression, of the relationships which existed between people.

\section{Notes}

1 Sayer and Wienhold (2012) used ArcGIS 10 software to calculate Ripley's K-function, to establish the extent of deviation from spatial homogeneity at multiple scales. From this data they generated kernel density plots, which exploit the point of significant clustering. Unfortunately, ArcGIS 10 contains problems with edge correction. For this current study Ripley's K-function has been generated in $R$, a free statistic program, using the maptools and spatstat plugins. The graphs generated for this book are available on the ADS webite at https://archaeology dataservice.ac.uk/. The kernel density or heat maps have been generated with the QGIS heatmap plugin. The results of the two studies are comparable, but here the distances have been calculated using point data based on the centre of each grave to allow comparison between cremation and inhumation graves. Sayer and Wienhold (2012) took measurements from polyline shape files.

2 The assessment of grave homogeneity can be carried out using whole or partial cemeteries because the important value is the distance between graves, not the graves themselves. The statistic will account for any evident pattern even if further graves are found. When the kernel density map is plotted - using the Ripley K-value if no patterns are evident, or if there are patterns in only part of the cemetery - then the site can be broken down into subsections for independent investigation. This is discussed later in the chapter, for example, in the cremations and inhumations at Apple Down or the northern and southern graves at West Heslerton, which were buried using different densities and were part of a deliberate spatial patterning.

3 This system of rows developed to help manage mortuary space but, in fitting large numbers into an ordered and relatively small space, the orientation was not always E/W (Sayer, 2011: 205).

4 For patterns of material culture at Apple Down, see Chapter 1; and for similar patterns at Morning Thorpe, see Chapter 6. 